\title{
Farklı Kariyer Evrelerindeki Öğretmenlerin Sürekli Öğrenen Okul Oluşturmaya İlişkin Zihni Modelleri
}

\section{Mental Models of Teachers at Different Career Stages Regarding to Establishing School As An Organisation Learning Continually}

\author{
Metin $\mathrm{ISSIK}^{* *}$, İsa BAHAT***
}

\begin{abstract}
Öz: Günümüzde, eğitim sisteminin öğrenmeyi öğrenen bireyler yetiştirme anlayışı gereği okulların öğrenen okul niteliğine ulaşması beklenmektedir. Bu amacı bireylerin düşünme yöntemlerini geliştiren zihni modeller sağlamaktadır. Bu çalışma da kariyer evreleri bağlamında öğretmenlerin öğrenen okul oluşturmaya ilişkin yaklaşım, algı ve görüşlerini belirlemek ve öğrenme süreçlerini irdelemek amaçlanmaktadır. Öğretmenlerin öğrenen okul oluşturma algılarının temelini oluşturan zihniyet ve yaklaşımları ile düşünce ve bakış açılarını değiştirmeleri öngörülmektedir. Farklı tür eğitim kurumlarında farklı branş ve kariyer evrelerindeki öğretmenlerin öğrenen okul oluşturmaya ilişkin zihni modelleri ve profesyonel gelişme ihtiyaçları betimlenmek amacıyla nitel bir süreç izlenmiştir. Çalışma grubu, amaçlı örnekleme yöntemlerinden ölçüt örnekleme yöntemi ile belirlenmiştir. Öğretmenlerin seçiminde araştırmacılar tarafından belirlenen temel ölçüt, katılımcıların bulunduğu kariyer evresidir. Araştırmada her kariyer evresinde dört olmak üzere İstanbul ili Beylikdüzü ilçesinde ilk, orta ve lise kademelerinde toplam yirmi öğretmen ile yarı yapılandırılmış görüşme tekniği kullanılarak yüz yüze görüşmeler yapılmıştır. Toplanan veriler nitel araştırma yöntemi doğrultusunda incelenerek içerik analizi ile değerlendirilmiştir. Öğrenen okul oluşturmada öğretmenlerin görüşleri beş disiplin tema algısı hâlinde toplam 19 alt tema oluşmuştur. Kariyer evrelerine göre öğretmenlerin öğrenen organizasyonlarda beş disipline yönelik zihni modelleri karşılaştırıldığında, farklı kariyer evrelerinin tamamında öğretmenlerin ortak algıya sahip oldukları ancak başarı, firsatlar, öğrenme ortamları, güven ve yeterlik alanlarında engellerle ilgili farklı düşündükleri görülmektedir. Zihni modeller, kariyere giriş evresinden sakinlik evresine doğru kademe kademe değişiklik göstermektedir. Türkiye'de eğitim kurumlarının kültürü, öğretmenlerin kişisel özellikleri ve öğrenme davranışları, öğrenen okul oluşturmada belirleyici olduğu görülmektedir.
\end{abstract}

Anahtar Kelimeler: Beşinci disiplin, öğrenen okul, kariyer evresi, kişisel gelişim

\begin{abstract}
Today schools are expected to become learning organisations according to the system approach via learning individuals to maintain their individual learning. This could only be ensured through mental models that might improve the way of thinking. This study aims to determine the viewpoints and perceptions of teachers regarding creating a learning school and to examine their learning process. It is assumed that teachers might change their thoughts and viewpoints about creating a learning school.. A qualitative process has been practised to describe and define mental models and professional development of teachers teaching different subjects at various career levels. The work group was determined according to the criterion sampling method. The basic criteria for teachers that has been dentified by researchers is their career stage Semi-structured face to face interviews have been carried out with 20 teachers performing at primary and secondary schools located in Beylikdüzü İstanbul district. The collected data has been examined via content analysis method. In creating a learning school, teachers' viewpoints generates 19 subthemes in the perception of the fifth discipline. As teachers' mental models on the fifth discipline are compared according to their career stages, it could be said that teachers have common perception but have different viewpoints about obstacles pertaining to success, opportunity, learning environment, safety and qualification concepts. Mental models might vary gradually from entry stage to resting stage. It is

\footnotetext{
** Doktor, Milli Eğitim Bakanlığı, Koç Ortaokulu, İstanbul, ORCID: https://orcid.org/0000-0002-0890-6267, e-posta: metinziya09@hotmail.com

*** Öğr. Gör., Kırşehir Ahi Evran Üniversitesi, Kaman Uygulamalı Bilimler Yüksekokulu, Kırşehir, ORCID: https://orcid.org/0000-0002-5600-2449, e-posta: isabahat@ahievran.edu.tr
} 
understood that the culture of educational institutions, teachers' personal traits and learning behaviours are of high importance in being determinative in establishing a learning school in Turkey.

Keywords: Fifth discipline, learning school, career phrases, personal improvement

\section{Giriș}

Öğrenme, bilgi edinmede devamlılık ve çevre etkileşimi ile davranışların gelişim göstermesidir (Töremen, 2001). Örgütsel öğrenme, örgütte farklı düzeylerde gerçekleşen öğrenme sonucunda oluşur (Koçel, 2003) ve örgüt kültürü ile öğrenmenin kapsamını çözer (Aytaç, 1999). Okullar bireyin düşünce, davranış ve yaşam amacını tespit etmektedir. (Fındıkçı, 1996). Bu yüzden okulların öğrenen sisteme sahip olabilmesi için bir değer olarak öğrenme gerekmektedir (Başaran, 2000). Öğrenen örgüt; çalışanın gelişmesi için öğrenmeyi ve güçlü iletişim ile değişen koşullara uyumda tecrübeleri kullanan, gelişen ve yenilenen bir sistem (Koçel, 2003) kurar. Sistem kuramını esas alan (Çelik, 2003) öğrenen örgütler, yönetim açısından bireylerin sürekli olarak geliştikleri (Senge, 2007) ve birlikte öğrendikleri, yeni yaklaşımların değer kazandığ1 (Yazıcı, 2001) oluşumlardır. Sistem düşüncesi öğrenmeyi, öğrenmede bakış açısı değişikliği yanında "insanın şimdiye kadar yapamadı̆̆ bir şeyi yapmasını sağlayan davranış ve düşünce değişiklikleri bütünü” olarak görmektedir (Ensari, 1998).

Sürekli öğrenme ile gelişme ve değişmenin kaçınılmaz olduğu toplumsal ve ekonomik örgütlenme dönemi olan (Ögüt, 2003) günümüzde elişen teknoloji için örgütlerin bilgi edinme ve değerlendirme için yapılanmalarını yenilemeleri gerekmektedir (Elma ve Demir, 2000). Öğrenme becerisini geliştirerek yeniliklere uyum sağlayabilmede örgütler, hız ve kapasite yönüyle farklıdır. Senge (2007)'ye göre öğrenen örgütler, "kişilerin gerçekten istedikleri sonuçları yaratma kapasitelerini durmadan genişlettikleri, yeni düşünme tarzlarının desteklendiği, insanların sürekli birlikte öğrendikleri organizasyonlar" olabilmek için birlikte, açık ve sınırsız bir yaklaşım gösterirler; bilgileri paylaşarak hızlı, doğru ve faydalı öğrenmeyi misyon haline getirirler (Elma ve Demir, 2000). İnsanlar birlikte, etkileşime açık paylaşım ile daha kolay öğrenirler. Öğrenmenin bireysel ve örgütsel bilgi ve davranışları farklı boyutlarda (Yazıc1, 2001) etkileyen değişim sebebiyle sistemler çevreyi algılamalı, izlemeli ve değerlendirmelidir (Morgan, 1998). Örgütler birlikte öğrenme (Yazıcı, 2001) ile sistematik problem çözme; tecrübelerinden ve başkalarından öğrenerek birlikte öğrenme yetilerini (Garvin, 1999) geliştirirler. Bireyler de kalite, yenilenme ve etki yönüyle kurumlarını geliştirirler. Kolay ve hızlı öğrenen birey ve örgütlerin öğrenme ihtiyacını belirleyebilmesi, hızlı ve etkili bir şekilde öğrenmesi, hızlı değişen bilgi ve teknolojiye uyum sağlamasını (Braham, 1998; çev. Tekcan, 1998) kolaylaştıracaktır.

Sistem yaklaşımı, öğrenme sürecini örgütsel boyutlarıyla inceleyerek öğrenen kişiler aracıllı̆̆yla örgütsel öğretmeyi sağlar. Öğrenen organizasyonda beş disiplinin birlikte gelişmesi büyük önem taşır (Senge, 2007: çev. İldeniz, 2002). Sistem düşüncesi öğrenen organizasyonlarda bireylerin kendilerini ve çevreyi anlamasını; kişisel ustalık disiplini, sürekli gelişmek için yaşam boyu öğrenme ve bilgiye ulaşma yöntemlerini bilerek örgütsel gelişme için ulaşılan yetkinlik düzeyini; kişisel hakimiyet, gerçekleri objektif görmeyi ve kişisel vizyonun sürekli olarak geliştirilmesidir. Bireysel öğrenme ve gelişme olarak kişisel hakimiyet, ögrenen organizasyonun temelidir. Takım halinde ögrenme, takımı asıl öğrenme birimi görür. Ortak bir vizyon geliştirmek ve kişisel ustalık, takım halinde öğrenmenin esas ögeleridir (Senge, 2007). Paylaşılan Vizyon, bireylerin paylaştığı ortak bir hedeftir (Senge, 2007). Zihni modeller disiplini ise var olan düşünce yapıları ile bakış açısılarını açıklar. Zihni modeller, bireylerin düşünme yöntemlerini geliştirirerek, düşünülenleri daha yararlı hale getirir (Senge 2007). İnsanlar duygu ve düşünceleri, sahip oldukları bilgi ve edindikleri deneyimleri ile çevrelerini, olayları, durumları ve insanları tanımlar ve yorumlarlar. Eylemlerimize ve düşüncelerimize yön veren "örtük varsayım ve tutumlar" (Senge, 2014) olan zihni modeller, zihnimizin derinliklerinde olan varsayımlar, genellemeler, kalıp düşünceler, ön yargılar ve imgelerdir. Büyüdügümüz kültür, benimsediğimiz örf ve adetler, inançlarımız, eğitim ve bilgi seviyemiz, gözlemlerimiz ve duygularımız aracılı̆̆ıyla şekillenen ve eylemlerimizi belirleyen bu düşünceler, genellikle bilinç düzeyimizin altında yer almaktadır. "Insanlar her zaman söyledikleri ile uyumlu olmasalar da, sahip oldukları zihni 
modellere uyumlu davranırlar. Zihni modeller hep eksik olmasına răgmen evreni zihni modeller aracılığıyla kavrarız" (İnceler, 1997).

Eğitimin ve sistemin bilgi toplumundaki asıl hedefi, bireylere öğrenmelerinde yardımc1 olarak öğrenmeyi öğrenen bireyler yetiştirmektir. Eğitim yönetiminin ise, okulu öğrenen okul özelliğine ulaştırmaktır. Sürekli öğrenmede eğitim sistemi, okul ve öğretmenlerin rolü çok önemlidir (Fındıkçı, 2004). Öğrenen okul, yenilik ve gelişime açık okul olarak diğer okul ve kurumlarla işbirliği yapmalı, gelişim ve yeniliğe yönelik işlerde sürekli aktif olmalıdır (Sarıtaş, 2001). Bunun için de öğrenen okullarda etkili bir değişim kültürü oluşturulmalı, sürekli gelişme, değişme ve yenilenmeye önem verilmelidir. Öğrenen okulda, bir değişim kültürü için (Özdemir, 2000):

1. Değişmeye uygun vizyon ve misyon tanımlanmalı,

2. Herkes tarafindan sahiplenilmeli,

3. Eğitimin tarafları tarafından katkı sağlanmalı ve desteklenmeli,

4.Değişimin farklı düzeylerinde tahmin edilmeyen durumlar da gözetilmelidir.

Eğitim, toplumdaki değişimlerden etkilenerek yenilenir ve toplumun yenileşmesinde de öncü olur (Özdemir, 2000). Aydın (2001)'a göre öğretmenlerin sürekli öğrenmesi eksikliklerini giderebilmesinde bir ihtiyaçtır. Bu yüzden sistem yaklaşımı okuldaki kişisel alg1 ve değerleri değiştirerek öğrenmeyi sürekli hale getirmeyi amaçlamaktadır. Çünkü öğretmenler, potansiyel olarak okulu öğrenen ve daha etkili bir örgüt yapmada anahtar bir rol oynarlar (Töremen, 2001). Değişen bilgi çağında okulların, öğrencilerin ihtiyacı olan bilgileri öğrenebilmesi öğrenmeyi öğrenme yeterliliğini kazanmalarına bağlıdır (Özden, 2001). Öğretmenler, öğrenmesi için gereken kültür, müfredat bilgisi ile mesleki bilgi ve becerilere sahip olmalıdır (Erden, 1998). Çağdaş toplumun öğretmeni; sorunları çözebilen, teknolojiyi kullanabilen, olumlu iletişim kurabilen, imkanları kullanarak eğitim ortamını aktif bir öğrenme ortamına dönüştürebilen; sürekli öğrenmeyi benimseyen ve toplumun gelişmesini destekleyen bir rol taşımaktadır (Ünal ve Ada, 2001). Çünkü okulda eğitimin niteliğini belirleyen iki temel öğe yönetici ve öğretmendir. Öğretmen, eğitim ve öğretim hizmetini sunar (Çelik, 2003). Okullar, öğrenmeyi destekleyen bir kültür oluşturmak, yenilikleri takip etmek ve eğitime fırsat sağlamak zorundadır. Çünkü dinamik bir süreç olan eğitimin her aşamasında insanın rolü önemlidir (Fındıkçı, 2004).

Bireyin deneyimlerinden oluşan kariyer bir gelişim süreci olarak, mesleki ilerleme, tecrübe edinme, sorumluluk alma ve saygınlık kazanmaktır (Tortop, 1994). Mesleki tecrübe, davranış ve iş konumunu gösteren kariyer, yaşam boyu süren davranışlar bütünüdür. Mesleki ilerleme için fazla sorumluluk almak, güç ve saygınlık kazanmak gerekmektedir (Can vd., 2006). Türkiye'de ise eğitim sistemi, öğrenen organizasyon anlayışına uygun yapılandırılmamıştır. Eğitim sistemi ile kurumlardan beklenen öğrenen organizasyona uygun yapılanmalarıdır. Türkiye' de eğitim kurumlarının kültürü, öğretmenlerin kişisel özellikleri ve öğrenme davranışları öğrenen okul oluşturulmasında belirleyicidir. Bu sebeple kariyer açısından birey ve örgüt öne çıkmaktadır. Bireyin kendini gerçekleştirmesi için mesleki konumunu tanıması, kişiliğini oluşturan özellikleri belirlemesi gerekmektedir. Örgütsel kariyer, kendi eğilimleri ve hedeflerinin doğrultusunda misyona uygun bireysel amaç ve yönelimlere uymaktır (Kaynak, 1996). Örgütsel hedeflere ancak kişisel çabalarla ulaşılabildiği için örgütlerin gelişmesi ve verimliliği her seviyedeki çalışanlarının performansına bağlıdır (Aytaç, 1999). Öğretmenlerin mesleki gelişimini içine alan kariyer gelişim evreleri, performanslarına bağlı olarak kariyer girişi, durulma, deneycilik, uzmanlık ve sakinlik evresi olarak beş yıllık beş evreden oluşur (Bakioğlu, 1996). Öğretmenlerin kariyer gelişimleri incelendiğinde gelişime istekli ve aynı evrede bulunan öğretmenlerin bir araya gelerek mesleki paylaşım fırsatı buldukları görülür. Öğretmenlerin gelişimi için yapılan etkili geliştirme etkinlikleri, kişilerin hem kendilerinin güçlü ve zayıf yönlerini daha iyi bilmelerine hem de birlikte çalıştıkları arkadaşlarının güçlü ve zayıf yönlerini tanımalarına yardımcı olur. Bakioğlu ve İnandı (2001), öğretmenin kariyer gelişimi sayesinde örgüte olan bağl1lığın artacağı ve kendini önemli hissetmesinin sağlanacağını belirtmektedir. 
$\mathrm{Bu}$ çalışmada kariyer evreleri bağlamında öğretmenlerin öğrenen okul oluşturmaya ilişkin yaklaşım, alg1 ve görüşlerini belirlemek ve yaşadıkları öğrenme süreçlerini irdelenmektedir. $\mathrm{Bu}$ amacı bireylerin düşünme yöntemlerini geliştiren zihni modeller sağlamaktadır. $\mathrm{Bu}$ araştırma ile öğretmenlerin öğrenen okul oluşturma algılarının temelini oluşturan zihniyet ve yaklaşımları ile sahip olunan düşünce kalıplarını ve bakış açılarını değiştirmeleri amaçlanmaktadır. Bu amaç doğrultusunda araştırmada aşağıda yer alan sorulara yanıt aranmıştır.

- Öğretmenlerin görüşlerine göre okullarında bireysel ve birlikte öğrenme deneyimleri nelerdir?

- Öğretmenlerin kariyer evreleri bağlamında öğrenen okul oluşturmaya ilişkin görüşleri nasildir?

- Öğretmenlerin öğrenmesinin öğrenen okul oluşturma sürecine etkisine ilişkin görüşleri nelerdir?

\section{Yöntem}

$\mathrm{Bu}$ araştırma ile farklı tür eğitim kurumlarında farklı branş ve kariyer evrelerindeki öğretmenlerin öğrenen okul oluşturmaya ilişkin zihni modelleri ve profesyonel gelişme ihtiyaçları betimlenmeye çalışılmıştır. Nitel araştırma; gözlem, görüşme, doküman analizi gibi nitel veri toplama yöntemlerinin kullanıldığı; algıların ve olayların doğal ortamlarında gerçekçi ve bütüncül bir biçimde ortaya konmasına yönelik nitel bir sürecin izlendiği araştırma olarak tanımlanmaktadır (Yıldırım ve Şimşek, 2005). Bu araştırma da nitel bir süreç izlenerek Beylikdüzü ilçesinde farklı branşta olan ve farklı kademe okullarda görev yapan 20 öğretmen ile görüşme yapılmıştır.

\section{Çalışma grubu}

Günümüzde modern toplumların bütünü içinde kendine özgü özellikleri olan alt gruplar oluştuğu ve her kademenin kendi başına bir evren olarak çalışılması mümkün görülmemektedir (Yıldırım ve Şimşek; 2005). Araştırmanın çalışma grubu amaçlı örnekleme yöntemlerinden ölçüt örnekleme yöntemi ile belirlenmiştir. Ölçüt örnekleme, örneklemin problemle ilgili olarak belirlenen niteliklere sahip kişiler, olaylar, nesneler ya da durumlardan oluşturulmasıdır (Büyüköztürk, Çakmak, Akgün, Karadeniz ve Demirel, 2009). Araştırmada, öğretmenlerin seçiminde araştırmacılar tarafından belirlenen temel ölçüt, katılımcıların bulunduğu kariyer evresidir. Araştırmanın amacına uygun çalışma grubu İstanbul ili Beylikdüzü ilçesinde farklı tür okullarda çalışan öğretmenlerin kariyer evreleri dikkate alınarak oluşturulmuştur. Araştırmada her kariyer evresinde dört olmak üzere, ilk, orta ve lise okul düzeyinde toplam yirmi öğretmen ile görüşmeler yapılmıştır. Beylikdüzü ilçesinde ilk, orta ve lise öğretmenleri ile yapılarak veriler toplanmıştır. Görüşmeler ses kaydı kabul edilmediği için aynı ortamda yazarak gerçekleştirilmiştir. Çalışma grubundaki öğretmenlere ait veriler Tablo 1'de görülmektedir. 
Tablo 1.

Öğretmenlerin Demografik Özelliklerine Ait Frekans ve Yüzde Dağılımı

\begin{tabular}{|c|c|c|c|c|c|c|c|c|c|}
\hline \multicolumn{10}{|c|}{ Kariyer Giriși Evresi 1/5 Yıl } \\
\hline $\begin{array}{l}\text { Sira } \\
\text { No }\end{array}$ & Cinsiyet & $\begin{array}{l}\text { Medeni } \\
\text { Durum }\end{array}$ & Yaş & $\begin{array}{l}\text { Mezuniyet } \\
\text { Durumu }\end{array}$ & $\begin{array}{l}\text { Mezun Okul } \\
\text { Türü }\end{array}$ & Kıdem & Branş & $\begin{array}{l}\text { H.içi } \\
\text { Eğitim } \\
\text { Sayısı } \\
\end{array}$ & $\begin{array}{l}\text { Kariyer } \\
\text { Basamağı }\end{array}$ \\
\hline 1 & Erkek & Bekar & $30 / 39$ & Lisans & Eğitim Fak & $1-5$ & Bilişim & 10 ve Üstü & Öğretmen \\
\hline 2 & Erkek & Evli & $30 / 39$ & Lisans & Eğitim Fak & $1-5$ & Bilişim & 10 ve Üstü & Öğretmen \\
\hline 3 & Kadın & Evli & $30 / 39$ & $\begin{array}{l}\text { Yüksek } \\
\text { Lisans }\end{array}$ & Fen Edeb. & $1-5$ & Türk Edb. & $0-3$ & Öğretmen \\
\hline 4 & Kadın & Evli & $20 / 29$ & Lisans & Eğitim Fak & $1-5$ & PDR & $4-6$ & Öğretmen \\
\hline \multicolumn{10}{|c|}{ Durulma Evresi 6/10 Yıl } \\
\hline 1 & Kadın & Bekar & $30 / 39$ & $\begin{array}{l}\text { Yüksek } \\
\text { Lisans }\end{array}$ & Eğitim Fak. & $6-10$ & Sinıf Öğrt. & $4-6$ & Öğretmen \\
\hline 2 & Kadın & Evli & $30 / 39$ & Lisans & Fen Edeb. & $6-10$ & Türkçe & $4-6$ & Öğretmen \\
\hline 3 & Erkek & Evli & $30 / 39$ & Lisans & Eğitim Fak. & $6-10$ & $\begin{array}{l}\text { Beden } \\
\text { Eğitimi }\end{array}$ & $0-3$ & Öğretmen \\
\hline 4 & Erkek & Evli & $40 / 49$ & Lisans & Fen Edeb. & $6-10$ & Sinıf Öğrt. & 10 ve Üstü & Öğretmen \\
\hline \multicolumn{10}{|c|}{ Deneycilik Evresi 11/15 Yıl } \\
\hline 1 & Erkek & Evli & $30 / 39$ & Lisans & Fen Edeb. & $11-15$ & Sinıf Öğrt. & 10 ve Üstü & Öğretmen \\
\hline 2 & Erkek & Evli & $30 / 39$ & Lisans & Eğitim Fak. & $11-15$ & Mat. & $7-9$ & Öğretmen \\
\hline 3 & Erkek & Evli & $30 / 39$ & Lisans & Fen Edeb. & $11-15$ & Mat. & $0-3$ & Öğretmen \\
\hline 4 & Kadın & Evli & $30 / 39$ & Lisans & Eğitim Fak. & $11-15$ & Biyoloji & $4-6$ & Öğretmen \\
\hline \multicolumn{10}{|c|}{ Uzmanlık Evresi 16/20 Yıl } \\
\hline 1 & Erkek & Evli & $40 / 49$ & Lisans & Eğitim Fak. & $16-20$ & Sinıf Öğrt. & 10 ve Üstü & $\begin{array}{l}\text { Uzman } \\
\text { Öğrt. }\end{array}$ \\
\hline 2 & Kadın & Evli & $30 / 39$ & Lisans & Eğitim Fak. & $16-20$ & $\begin{array}{l}\text { Görsel } \\
\text { Sanat }\end{array}$ & $4-6$ & Öğretmen \\
\hline 3 & Erkek & Evli & $40 / 49$ & Lisans & Eğitim Fak. & $16-20$ & Sinıf Öğrt. & $4-6$ & Öğretmen \\
\hline 4 & Erkek & Evli & $30 / 39$ & $\begin{array}{l}\text { Yüksek } \\
\text { Lisans } \\
\end{array}$ & Fen Edeb. & $16-20$ & $\begin{array}{l}\text { Türk } \\
\text { Edeb. }\end{array}$ & $0-3$ & Öğretmen \\
\hline \multicolumn{10}{|c|}{ Sakinlik Evresi 21 Yıl ve Üzeri } \\
\hline 1 & Erkek & Bekar & $\begin{array}{l}50 \text { ve } \\
\text { üstü }\end{array}$ & Lisans & Eğitim Fak. & $\begin{array}{l}21 \text { ve } \\
\text { Üstü }\end{array}$ & $\begin{array}{l}\text { Beden } \\
\text { Eğt. }\end{array}$ & $0-3$ & Öğretmen \\
\hline 2 & Erkek & Evli & $40 / 49$ & Lisans & Eğitim Fak. & $\begin{array}{l}21 \text { ve } \\
\text { Üstü }\end{array}$ & $\begin{array}{l}\text { Sosyal } \\
\text { Bil. }\end{array}$ & 10 ve Üstü & $\begin{array}{l}\text { Uzman } \\
\text { Öğrt. }\end{array}$ \\
\hline 3 & Erkek & Evli & $40 / 49$ & Doktora & Fen Edeb. & $\begin{array}{l}21 \text { ve } \\
\text { Üstü }\end{array}$ & Sinıf Öğrt. & 10 ve Üstü & $\begin{array}{l}\text { Uzman } \\
\text { Öğrt. }\end{array}$ \\
\hline 4 & Erkek & Evli & $40 / 49$ & Lisans & Eğitim Fak. & $\begin{array}{l}21 \text { ve } \\
\text { Üstü }\end{array}$ & $\begin{array}{l}\text { Türk } \\
\text { Edeb. }\end{array}$ & 10 ve Üstü & $\begin{array}{l}\text { Uzman } \\
\text { Öğrt. }\end{array}$ \\
\hline
\end{tabular}

Tablo 1'de katılımc1 öğretmenlerin \%80'ini erkek, \%20'si kadın; \%85'i evli, \%15'i ise bekar oldukları; \%20'sinin lisansüstü, \% 20'sinin ise lisans düzeyinde eğitim seviyesinde oldukları ve \%30'u sınıf öğretmenliği, \%70'i ise farklı branşlarda öğretmenlik yapmaktadır. Katılımcıların \%65'i eğitim fakültesi, $\% 35$ 'i ise fen edebiyat fakültesi mezunu olarak görülmektedir. Bakioğlu'nun (1996) öğretmenlerin kariyer evreleri yaklaşımına göre; katılımc1 öğretmenlerin \%20'si (4) kariyere giriş evresinde, \%20'si (4) durulma evresinde, \%20'si (4) deneycilik evresi, \%20'si (4) uzmanlık evresi ve \%20'inin de (4) sakinlik evresinde bulunmaktadır. Katılımcıların \%80'i (16) uzman öğretmen, \%20'si (4) öğretmen olarak görev yapmaktadır. Ayrıca \%25'i 1 ile 3, \%30'u 4 ile 6, \%5'i 7 ile 9 ve \%40'1 ise 10 ve üstü sayıda hizmet içi eğitime katıldıkları görülmüştür.

\section{Veri toplama aracı}

$\mathrm{Bu}$ çalışmada veri toplama yöntemi olarak yarı yapılandırılmış görüşme tekniği kullanılmıştır. Bu yöntem ne tam yapılandırılmış görüşme kadar katı ne de yapılandırılmamış görüşme kadar esnektir; iki uç arasında yer almaktadır (Karasar, 2015). Bu nedenle daha önceki literatür 
bilgilerinden ve uzman görüşlerinden yararlanılarak, araştırmanın amacına hizmet edecek şekilde yarı yapılandırılmış bir görüşme formu hazırlanmışıır. "Görüşme" konusunda ilgili literatür incelenmiş ve dikkat edilecek konulara özen gösterilerek; benzer ortamların sağlanmasına özen gösterilmiştir. Yarı yapılandırılmış form ile gerçekleşen yüz yüze görüşmeler, "bakış açılarını ortaya koyan sözcükleri" (Bogdan ve Biklen, 2007) anlamak için firsat olarak kullanılmaktadır. Görüşme soruları, kapsam geçerliliğini tespit etmek ve dil bilgisi açısından değerlendirilmek amacıyla eğitim yönetimi alanında uzman 4 akademisyen ile 2 Türk dili uzmanının değerlendirmesine sunulmuştur. Ayrıca uzman görüşü için 5 öğretmenle ön görüşme gerçekleştirilmiştir. İlk görüşmelerden elde edilen veriler 1şığında görüşme soruları tekrar gözden geçirilmiş ve iki araştırmacının kontrolünden sonra nihai şekli verilmiştir. Geliştirilen görüşme formu ile 25 öğretmene görüşme teklif edilmiş, görüşmeyi kabul eden 20 öğretmen ile çalıştıkları okulda kendi seçtikleri ortamda yüz yüze görüşme yapılmıştır.

Uygulamada görüşme yapılan öğretmenlerin isteğiyle kayıt cihazı kullanılmamıştır. Görüşmeler 30-60 dakika arasında bir sürede tamamlanmıştır. Görüşülen öğretmenlerin demografik özelliklerini gösteren bilgiler, değerlendirildikleri kariyer evresi içinde görüşme sırasına göre numaralandırılarak Tablo 1'de verilmiştir. Araştırma içinde de görüşünü bildiren öğretmenin, değerlendirilen evre içinde aynı kodlamayla yer alması, hem demografik bilgilerine hem de öğrenen okul oluşturmaya ilişkin beş disiplin hakkındaki görüşlerine ulaşılmasını kolaylaştırmak için kullanılmıştır. Görüşme yapılan öğretmenlerin her birine Senge'nin beş disiplininden her disipline ait iki soru yöneltilmiştir. Katılımcı öğretmenler toplamda demografik bilgiler için sorulan sorular dışında yarı yapılandırılmış on soruya ve alt sorulara yanıt vermişlerdir. Verilerin güvenirliğini sağlamak için kayıtlar ve dökümler araştırmacılar dışında bir araştırmacı tarafından da incelenmiş ve araştırmacıların dökümleri ile karşılaştırılmıştır (Uzuner ve Çolak 2004: Akt. Y1lmaz ve Altınkurt, 2011).

\section{Verilerin analizi}

Toplanan veriler nitel araştırma teknikleri doğrultusunda incelenerek içerik analizi ile değerlendirilmiştir. Görüşmeler sırasında notlar alınmış; aynı zamanda görüşme yapılan kişiler paylaşılan forma görüşlerini yazmışlardır. Araştırmada görüşlerini bildiren her öğretmene bulunduğu kariyer evresi içinde bir numara verilmiş; öğretmenlerin özgün görüşleri sonuna o öğretmenin numarası G1, G2, G3... yazılmıştır. Aynı zamanda ilgili öğretmenin demografik özellikleri, bulunduğu kariyer evresinde de bu numarası ile Tablo 1'de yer almaktadır. Araştırma sonucunda elde edilen bulgular beş disipline göre tema ve alt tema olarak sınıflandırılmıştır. İçerik çözümlemesi model, tema ve anlamı ortaya çıkarmak amacıyla bir metnin dikkatli, ayrıntılı, sistematik olarak incelenmesi ve yorumlanması olarak tanımlanmaktadır (Büyüköztürk, 2012). $\mathrm{Bu}$ aşamada araştırmanın güvenilirliğini arttırmak için birinci ve ikinci araştırmacılar, her bir ifadeyi ayrı ayrı çözümlemişler ve içerik analizinde $\mathrm{K} 1, \mathrm{~K} 2, \mathrm{~K} 3 \ldots$ şeklinde kodlamalar ile her bir formu incelemişlardir. Farklı durumlarda yeniden değerlendirme yapılarak uzlaşılmıştır. Kodlar altında toplanan ifadeler, öğrenen okul oluşturma konusunda öğretmenlerin görüşleri doğrultusunda beş disiplin zihni modeller, kişisel ustalık, paylaşılan vizyon, takım halinde öğrenme ve sistem düşüncesi esas alınarak beş tema altında bahsi geçen ifadeler kısaca anlamlandırılıp frekans çıkarma işlemi yapılmıştır. Toplam 19 alt tema ifade edilmiştir. Araştırmanın geçerliğinin ve inandırıcılığının arttırılması için cevaplarına yer verilmiştir.

Görüşmelerden yola çıkılarak oluşturulan kodların sınıflandırma aşağıdaki gibidir:

1. Zihni Modeller Disiplinine Yönelik Alg1

1.1. Kurum Başarısı

1.2. Öğretmenin rolü

1.3. Öğrenme firsatları

1.4. Öğrenme engelleri

1.5. Önyargilar

1.6. Yönetici ve öğretmen görüş farkl1lık ve benzerlikleri

2. Kişisel Ustalık Disiplinine Yönelik alg1 
2.1. Öğrenme Ortamları

2.2. Yeterlikler

2.3. İhtiyaçlar

3. Paylaşılan Vizyon Disiplinine Yönelik alg1

3.1. İçselleştirme

3.2. İnandırıcılik

3.3. Sorun çözme

4. Sistem Düşüncesi Disiplinine Yönelik alg1

4.1. Sorunlar

4.2. Çözüm Arayışları

5. Takım Halinde Öğrenme Disiplinine Yönelik alg1

5.1. Mesleki Paylaşım

5.2. Birlikte öğrenme

$\mathrm{Bu}$ çalışmanın amacı farklı kariyer evrelerinde bulunan öğretmenlerin öğrenen organizasyonlara yönelik zihni modellerini belirlemektir. Katılımcılara öğrenen organizasyonlarda beş disiplin ile ilgili sorular sorularak, her bir disipline yönelik zihni modeller belirlenmeye çalışılmıştır. $\mathrm{Bu}$ nedenle değerlendirme aşamasında her bir disiplinle ilgili oluşturulan kodlar kariyerlere göre ele alınmış ve kariyer basamaklarına göre zihni modellerde oluşan değişim yansıtılmıştır.

\section{Bulgular}

\section{Farklı Kariyer Evrelerindeki Öğretmenlerin Zihni Modeller Disiplinine Yönelik Algıları}

Öğrenen örgütlerin öğrenme disiplinlerinin ilki olarak tanımlanan zihni modeller hakkında iki temel ve iki alt olmak üzere toplam dört soru sorulmuştur. Bu sorularla ilgili çalışmada verilen cevaplardan elde edilen verilerle toplam 6 kod oluşturulmuştur. Bunlar:

- Başarı

- Öğretmenin Rolü

- Firsatlar

- Engeller

- Önyargilar

- Bakış Açıları

Yapılan görüşmelerde öğretmenlerin kariyer evreleri ilerledikçe zihni modellerle ilgili olumlu yönde gelişim gösterdikleri düşünülmektedir. Özellikle başarı, öğretmenin rolü, firsatlar ve bakış açıları kodlarında kıdemin yüksek olduğu kariyer evrelerinde olumlu zihni modeller dikkat çekmektedir. Araştırmada görüşülen 20 katılımcının zihni modellere yönelik görüşlerinden elde edilen bulgular aşağıdaki Tablo 2'de verilmiştir. 
Tablo 2 .

Farklı Kariyer Evrelerindeki Öğretmenlerin Zihni Modellere İlişkin Algıları

Demografik

Başarı

Öğretmenin

Firsatlar

Engeller

Önyargilar

Bakış açıları

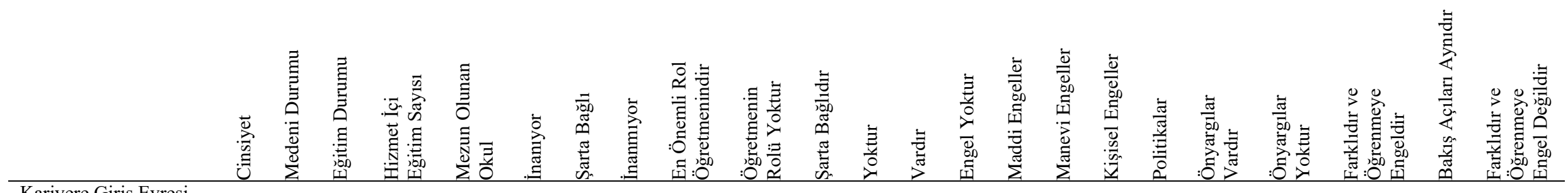

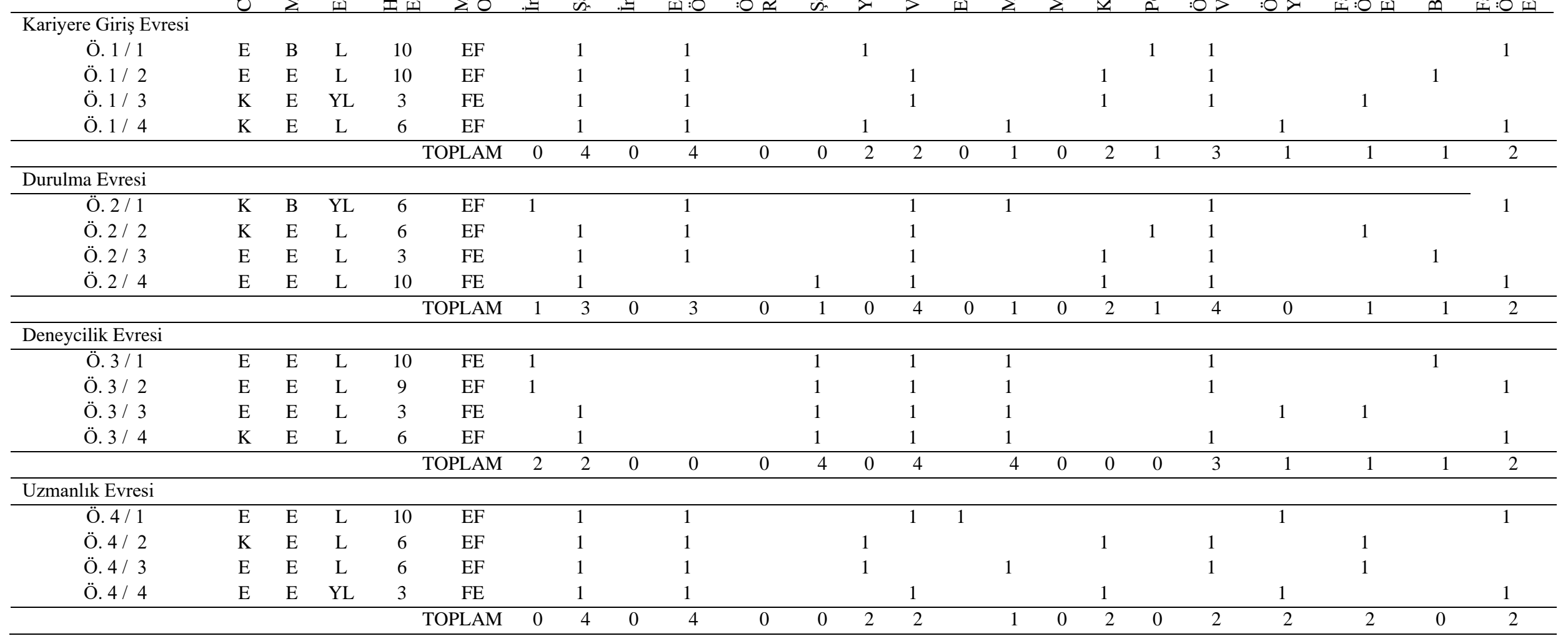


Farklı Kariyer Evrelerindeki Öğretmenlerin Sürekli Öğrenen Okul Oluşturmaya İlişkin Zihni Modelleri

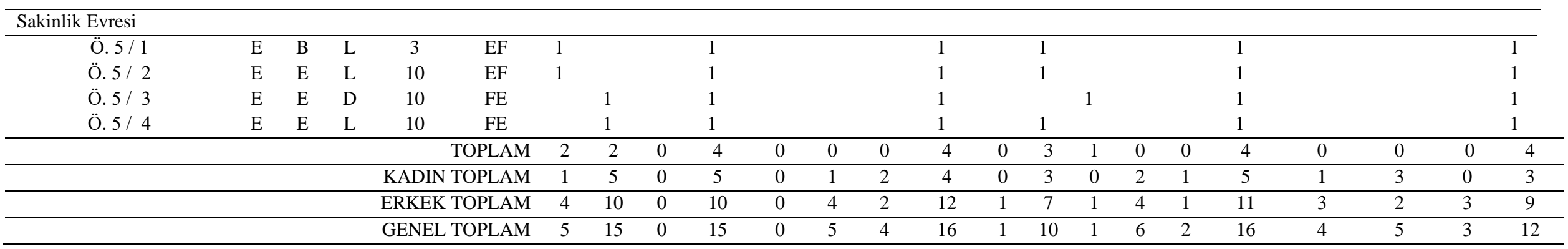




\section{Kurum başarısı}

Araştırmada katılımcı öğretmenlerin kariyer evrelerinde kurum başarısına inandıkları ancak çoğunluğunun başarıyı belli şartlara bağlı gördükleri ifade edilmektedir. Cinsiyet değişkenine göre kadın ve erkek katılımcıların görüşlerinin değişmediği görülmektedir. Mezun olunan okul değişkeni açısından Eğitim Fakültesi mezunlarının ve Fen-Edebiyat Fakültesi mezunlarının çoğunluğu başarıyı şarta bağlarken, bir kısmının kurum başarısına şartsız inandıkları görülmektedir. Kariyere giriş evresinde bulunan öğretmenlerin tamamı, kurumlarının akademik ve sosyal alanda başarılı olacaklarına inanmalarına rağmen, bu durumun gerçekleşebilmesi için;

- Okul yönetiminin eğitime bakış açısının değişmesinin,

- Kurumsal kimliğe sahip olması, bürokrasi ve adam kayırmacıllı̆ının ortadan kalkmasinın,

- Hata ve eksikliklerden ders çıkarılmasının,

- Sürekli eğitimin cazip hale getirilmesinin gerekli olduğunu ifade etmişlerdir.

Kurumumun gelecekte başarllı olabilmesi için okul yönetiminin eğitime bakış açısının değişmesi gerekmektedir. (1/1)

Cazip hale getirilen sürekli eğitimlerin kurumu ve mesleği daha başarılı hale getireceğini düşünüyorum. (1/4)

Durulma evresinde bulunan öğretmenlerin çoğunluğu başarıyı tecrübe, bilgi, motivasyon ve hizmet içi eğitim gibi şartların gerçekleşmesine bağlı görmektedirler:

Başarllı bir kurumda çalışıyorum... motivasyon şart. (2/3)

Kurumumun gelecekteki başarısı için ögretmenlerin akademik anlamda hizmet içi eğitimlere tabi tutulması gerekmektedir. (2/4)

Deneycilik/Aktivizm evresindeki öğretmenlerin tamamı kurumlarının gelecekte başarılı olacaklarına inandıklarını, bazıları ise başarının belli şartlara bağlı olduğunu ifade etmişlerdir.

Kurumların en başındakilerden en sonundakine kadar birlik bütünlük içinde olması gerekir. ...olumsuzluklar giderilirse başarılı olacağımıza inanıyorum. (3/2)

Kurumumuzun gelecekte başarılı olması Bakanlı̆̆ın eğitim politikasına ve kaynak ayırmasına bağll. (3/3)

Uzmanlık evresinde bulunan katılımcılar kurum başarısını fiziksel, mali ve eğitimsel eksikliklerin giderilmesine bağlı olduğunu ifade etmektedir.

Altyapı sorunlarının, fiziki yapıdan kaynaklanan eksikliklerin, finansman sorunlarının çözülmüss olması gerekir. (4/3)

Sahip olduğu olumlu nitelikleri kaybetmeden çağın gereklerine uygun yenilikler gerçekleştirirse kurumum başarılı olmaya devam eder. (4/4)

Sakinlik evresindeki öğretmenlerin çoğunluğu kurumlarının gelecekte daha başarılı olacağını, eğitim sistemindeki olumsuzlukların başarıyı etkilediğini belirtmişlerdir.

Kurumum gelecekte daha başarılı olacaktır. Kurumun yapısı yeni eğitim politikaları yönünde düzenlenecektir. (5/1)

Elbette başarılı olunabilir. Ancak yazboz sistemi devam ettiği müddetçe başarının artmasi zor. (5/4)

Görüşme yapılan farklı kariyer evrelerindeki katılımcıların kurum başarısına yönelik algılarının olumlu olduğu görülmektedir.

\section{Öğretmenin rolü}

Katılımcıların çoğunluğu başarıda öğretmenin önemli olduğunu, diğerleri ise öğretmenin rolünün sinırlandırıldığını ve bazı şartlara bağlı olduğunu ifade etmektedirler. Cinsiyet değişkeni açısından "öğretmenin rolü" algılarının farklılaşmadığı; mezun olunan okul değişkeni açısından Eğitim Fakültesi ve Fen Edebiyat Fakültesi mezunlarının çoğunluğunun öğretmenin rolünün önemini vurguladığı; diğerlerinin ise öğretmen rolünü şarta bağladığ görilmektedir. Mezun olunan okul değişkeninde anlamlı bir fark bulunmamaktadır. Kariyere giriş evresi öğretmenleri, kurumlarında kendilerine yeterince sorumluluk verilmediğini, ders programlarının kısıtladığını, programları sorgulamadan uyguladıklarını ve farklı etkinliklerde bulunamadıklarını ifade 
etmişlerdir.

Kurumumda kimse benden farklı olmamı beklemiyor. Çoğu tecrübeli öğretmenden ne yaptı̆̆ın değil dosyanda neler olduğu önemli cümlesini duyuyorum. Ben de buna uydum sanirim (1/4)

Yapmam gerekenleri yaptığım sürece başım ağrımıyor. Kimse de benden başka bir şey istemiyor (1/2)

Kariyere giriş evresinde bulunan öğretmenler sistem içinde kendilerine yeterince sorumluluk verilmediği yönündeki görüşleri, öğretmenin rolünü yeterince özümseyemediğine yorumlanabilir. Kariyere giriş evresi dışındaki evrelerde öğretmenin rolüne yönelik zihni modellerde farklılık görülmektedir. Durulma evresinde öğretmenler, başarının merkezinde öğretmenin bulunduğunu, gelecekteki başarının temelinde öğretmeni görmekte ancak öğretmenlerin akademik alanda hizmet içi eğitim almaları ile daha etkin olacaklarını vurgulamaktadir.

Okulların başarlsı ögretmene bă̆lıdır. (2/2)

Ögretmenler okul başarısının temelidir. Ancak daha etkin olmaları için öğretmenlerin akademik anlamda hizmet içi eğitimlere tabi tutulması gerekmektedir. (2/4)

Deneycilik/aktivizm, uzmanlık ve sakinlik evresindeki katılımciların tamamı, öğretmenlerin kurum için vazgeçilmez olduğunu ancak sakinlik evresindeki öğretmenler uygulanan eğitim politikalarına bağlı olarak öğretmen rolünün değiştiğini etmektedir.

Öğretmen kurumdaki değiş̧im, gelişim ve yenilenmenin temelidir. (3/4)

Eğitim anlayışı ne olursa olsun başarısı ögretmenin kalitesiyle mümkündür. (4/3)

Farklı kariyer evrelerindeki katılımcıların tamamı öğretmenlerin öğrenmede en önemli unsur olduğunu vurgulamışlardır. Bakioğlu (1996) araştırmasına göre, durulma evresinden itibaren öğretmenlerin kapasitelerini kullanma ve okulu öğrenme ortamı olarak algılamada evrelerde olumlu yönde geliştiğini ortaya koyması araştırmanın bulgularını desteklemektedir.

\section{Firsatlar}

Farklı kariyer evrelerindeki katılımcıların çoğunluğu kurumlarında öğrenme firsatları sunulduğunu ifade etmektedirler. Erkek katılımcıların tamamı, kadın katılımcıların ise çoğunluğu öğrenme firsatları sunulduğunu; Fen-Edebiyat fakültesi mezunlarının tamamı, eğitim fakültesi mezunlarının ise çoğunluğu öğrenme firsatlarının olduğunu ifade etmişlerdir. Kariyere giriş evresindeki öğretmenler, kurumlarında öğrenme ve sorgulamaya yönelik firsatların yetersiz olduğunu, kendilerine kurumlarında değer görmelerini önemli bir firsat olarak görmektedir. Öğrenme firsatlarının sunulmasına dair örnek ifadeler aşağıda verilmiştir:

Kurumumda mevcut durumuтuzu sorgulama ve öğrenme için firsat bulamiyorum. Daha çok engellerle karşılaşıyorum. (1/1)

Bilginin paylaşıldı̆̆ı okulumda sahip olduğum bilgi dolayısıyla önemseniyorum. (1/3)

Durulma ve deneycilik/aktivizm evresindeki katılımcı öğretmenler, kariyere giriş evresine göre daha olumlu olarak kurumlarında hizmet içi eğitim vb. seminerler düzenlendiğini ancak firsatlardan yararlanılamadığını; deneycilik evresi öğretmenleri ise, kariyere giriş ve durulma evrelerine göre çok daha net olarak öğrenme firsatlarını belirtmekle birlikte bu fırsatlardan kişisel sebepler nedeniyle yararlanamadıklarını ifade etmektedirler.

Yüksel lisans, hizmet içi eğitim ve seminerler var. Hizmet içi eğitimlerin birçoğunun modern fikirli ve cazip olmadığını düşünüyorum. (2/3)

Hizmet içi eğitim, lisansüstü çalı̧̧malar, seminerler ve özel kursalar gibi firsatlar var ancak ben yeterince faydalanamiyorum. (3/1)

Kariyere giriş ve durulma evresinde öğrenme firsatlarını bulma konusunda çevreyi suçlama eğilimi ortadan kalkmaktadır. Uzmanlık evresinde bulunan öğretmenler öğrenme fırsatlarının olmadığını ya da var olan öğrenme fırsatlarından şartlar ve kişisel engeller sebebiyle yararlanamadıklarını ifade etmişlerdir. 
Göstermelik de olsa hizmet içi eğitimler, kurslar, seminerler düzenlenmekte ancak bunları firsat olarak görmüyorum. (4/2)

Tembellik, Zaman sikıntısi, Motivasyon eksikliği varken firsatlardan söz etmek mümkün değgil. (4/4)

Firsatlar konusunda kariyere giriş evresinden itibaren olumlu gelişme gözlemlenmektedir. Ancak uzmanlık evresindeki öğretmenler öğrenme firsatlarının faydasına inanmamakta ya da mevcut firsatların kullanılamamaktadır. Sakinlik evresinde bulunan öğretmenler ise, kurumlarında öğrenme firsatlarının bulunduğunu ya da sürekli olarak yeni firsatların oluş̧urulmaya çalışıldığı şeklinde iyimser görüş bildirmişlerdir.

İhtiyaçlarımıza göre eğitim planlamaları yapılmaya çalışılmaktadır. Hizmet içi eğitim faaliyetleri ve kursalar ilk olarak aklıma geliyor. (5/1)

Ögretmenler arası paylaşım en güzel ögrenme ortamı. Ama kurumsal olarak yapılan eğitim faaliyetleri de var. (5/3)

Alanyazın incelendiğinde araştırma bulgularının desteklendiği görülmektedir. Bakioğlu (1996), bu evre öğretmenlerinin \%87'sinin kapasitesinin tamamını kullanma imkanı bulduğunu ve evreler arasında bu soruya en olumlu cevabı sakinlik evresi öğretmenleri vermektedir. Benzer şekilde bu evre öğretmenlerinin \%88'i okulda profesyonellik gereği öğrenmenin gerçekleştiğini, öğretmenlere sürekli öğrenme firsatları sunulduğunu ve bu yüzden okula bağl1lık duyduklarını belirtmektedirler.

\section{Engeller}

Zihni modellere yönelik görüşlerin en fazla çeşitlendiği, öğrenme ve öğrenme ortamlarına yönelik engeller oluşturmaktadır. Maddi imkansızlıklar, kişisel engeller, eğitim politikalarından kaynaklanan engellerden, manevi engeller çoğunlukla öğrenmenin önündeki engeller olarak görülmektedir. Cinsiyet ve mezun olunan okul türlerinde de sonuçlar genellikle benzerlik göstermektedir. Kariyere giriş evresindeki öğretmenlerin çoğunluğu, öğrenme engellerinin varlığını, hizmet içi eğitim faaliyetlerinin azlığını ve yetersizliğini engel olarak ifade etmektedir. Bakanlığın bakış açısı, maddi imkansızlıklar ve kişisel donanım da hizmet içi eğitim faaliyetlerden faydalanmanın önünde öğrenme engeli olarak görülmektedir. Öğrenme engellerinin varlığı ile ilgili öğretmen görüşlerinden bazıları şunlardır:

Bakanlı̆̆ın hizmet içi eğitim faaliyetlerine bakış açısl, hizmet içi eğitim faaliyetlerinin niteliği ve eğitimleri uygulama zamanlarından dolayı son yıllarda hizmet içi eğitim faaliyetlerine katılımı azaltmışıtır. (1/1)

Maddi durum ve hizmet içi eğitim için sıra gelmemesi, kurumumda yeterince sorumluluk alamamam ögrenme yönünde bana engel oluşturmaktadır. (1/4)

Kariyere giriş evresinde bireysel sebepler ve eğitim sistemi engel olarak görülmektedir. Bireyin kendi eksikliklerini görebilmesi öğrenen organizasyon oluşturmada uygun zihni modellere ulaşmada en önemli aşamalardan biridir. Öğrenen organizasyonlar içinde, önceden oluşan zihnî modeller yıkılmaktadır. Bunu sağlamak için kişisel eksikliklerin fark edilmesi gerekir.

Öğrenmeye ilişkin herhangi bir engel olduğunu düşünmüyorum. (1/2)

Durulma, deneycilik/aktivizm ve sakinlik evresinde yer alan öğretmenler, öğrenme firsatlarına sahip olsalar bile isteklerini kaybettiklerini, maddi ve manevi imkansızlıklarını öğrenme engeli gördüklerini ifade etmektedirler.

Mali nedenler, ailevi nedenler engel oluşturuyor. (2/1)

Zaman, Para, Çocuğuma bakacak kimsenin olmaması. Bütün bunlar varken diğer engelleri saymaya gerek yok. (3/1)

Uzmanlık evresinde ise öğretmenlerin bazısı öğrenme firsatlarının olmadığını, diğerleri ise var olan öğrenme firsatlarının şartları ve kişisel engeller sebebiyle yararlanamadıklarını ifade etmişlerdir.

Firsatlardan yararlanma konusunda kurumsal anlamda engel bulunmamaktadır. (4/1)

Tembellik, Zaman sikıntısı, Motivasyon eksikliği. (4/4) 


\section{Önyargılar}

Zihni modellerin belirlenmesinde önyargılar ve öğrenmeye etkisi konusunda katılımcılar önyargıları öğrenme engeli görmektedir. Öğretmenlerin bir kısmı ise genelin aksine önyargılarının olmadığını belirtmişlerdir. Cinsiyet ve mezun olunan okul değişkenine göre önyargılar ile ilgili de benzer sonuçlara ulaşılmaktadır.

Kariyere giriş ve uzmanlık evresindeki öğretmenlerin çoğu, durulma, deneycilik/aktivizm ve sakinlik evresinde ise tamamı önyargıların öğrenmeyi engellediğini ancak öğrenme firsatlarını etkilemediğini belirtilmiştir. Uzmanlık evresi dışındaki kariyer evrelerindeki öğretmenler, önyargılar bir öğrenme ve öğrenme firsatlarının önünde engel olarak görmektedir.

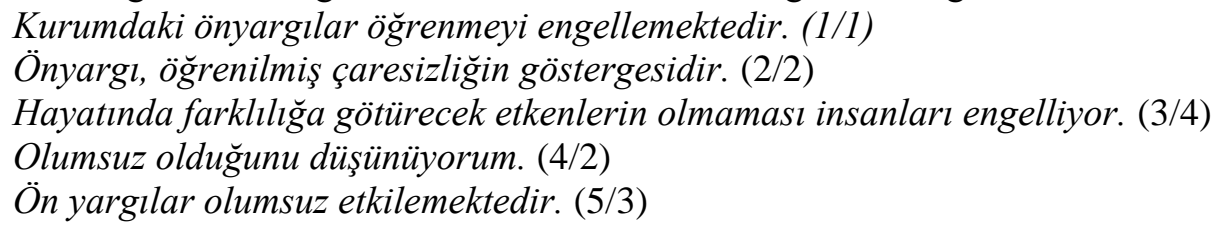

\section{Bakış açıları}

Öğretmenlerin öğrenme ve öğrenen organizasyona yönelik bakış açıları konusunda farklı bakış açılara sahip olduğu ancak bu farklılığın öğrenmeye engel oluşturmadığ 1 ve bir zenginlik olarak öğrenme ortamını desteklediği belirtilmektedir. Bazı öğretmenlerin farklı bakış açılarının ortak bir öğrenme ortamı önünde engel oluşturduğunu düşünmektedirler. Cinsiyet değişkenine göre ise katılımcıların yarısı öğretmenlerin farklı bakış açılarına sahip olduğunu ancak bu farklılığın öğrenmeye engel oluşturmadığını; diğer yarısı ise öğretmenlerin farklı bakış açılarına sahip olduklarını ve bu farklılıkların ortak bir öğrenme ortamı oluşturmada engel oluşturduğunu düşünmektedirler. Kariyere giriş evresindeki öğretmenler, öğretmenlerin kendilerini sıradan bakış açısına sahip olduğu için yöneticilere uzak gördüklerini ve belirli bazı hedeflerini yerine getirmek dışında bir kaygılarının olmadığı algısına sahip görülmektedir. Durulma evresi ile kariyere giriş evresi arasında benzerlik görülmektedir.

Müdür ve müdür yardımcılarının bakış açıları, yaş ortalamasına ve çalışma sürelerine bağlı olarak farklılıklar göstermektedir. Kurum içinde standartların ve hedeflerin olmaması veya hedeflerin değişmemesi, ögrenmeyi sıradan hale getirir ve çalışanların görüşleri benzer hale gelir. (1/1)

Çoğu kez farklı oldukların görüyorum. Yönetici ve ögretmenlerin eğitim seviyeleri ve mezun oldukları eğitim kurumları belirleyici olmaktadır. (2/1)

Deneycilik/Aktivizm evresinde de öğretmenler yaş, devlet memuru olma, bakış açısı kaynaklı farklılıkları kabul ederken, somut benzerlik bulunmadığını ifade etmişlerdir.

Bakış açıları birbirinden farklı. Yöneticileri daha çok rakamlar ve istatistiklere odaklanmış durumda. Öğretmenler öğrenciyle daha fazla iletişim halinde olduğundan işin insani yönünü ön plana çıkarmaktadır. (3/1)

Kurumlardaki idareci, ve öğretmenler yaşları ile alakalı görüs farklılıkları var. (3/2) Uzmanlık evresinde de öğretmenlerin tamamı yönetici ve öğretmen görüşlerinde farklılıklar olduğunu ancak öğrenme üzerinde engel oluşturmadığını ifade etmişlerdir. Farklılık gerekçesi olarak; kıdem yılı, prosedürler, yapısal değişiklikler, uygulama birliğinin olmaması ve aşırı öz güvenli idareciler olarak ifade etmişlerdir. Bu evrede özellikle farklılıkların öğrenme üzerine engel teşkil etmediğinin belirtilmesi dikkat çekicidir. Bu durum öğretmenlerin kendine güveni ve farklılıklardan faydalanılabileceğini düşünmeleriyle açıklanabilir.

Çok farklllık var. Prosedürler önümüzde çok fazla engel oluşturuyor. Yeni fikirlere (uygulamada emek harcanması gerektiği için) genellikle kapalıyız. (4/2)

Aşırı öz güvenli idarecilerle çalışmanin olumsuz tarafi işte bu noktada başlyyor. Bu tür idareciler uygulamada aşırı ısrarcı olabiliyorlar. Ciddi fikir farklılıkları uzun zaman 
içinde oluşan karşıllıklı güven ile aşılabiliyor. (4/4)

Sakinlik evresinde bulunan öğretmenler, öğrenme konusunda yönetici ve öğretmenler arasındaki benzerlik ve farklılıkları ile ilgili birbirlerinden farklı görüşlere sahiptir. Katılımcı öğretmenler, bu evrenin özelliklerine uygun olarak daha kendine güvenlidirler.

Çalışma yaşamı ile sosyal yaşam arasındaki çeliş̧kiler çalışma şartlarının yoğunluğu ögrenme sürecini etkilemektedir. (5/2)

Ögretmenler ögrenme ortamlarının ve hazır bulunuşluk düzeylerinin yetersiz olduğunu düşünmektedirler yöneticiler ögretmenlerin yetersiz olduğunu düşünmektedir. (5/3)

\section{Farklı kariyer evrelerindeki öğretmenlerin kişisel ustalık disiplinine yönelik algısı}

Öğrenen örgütlerin öğrenme disiplinleri olarak da tanımlanan beş disiplin içinde bireyleri tanımlayan kişisel ustalık disiplini ile ilgili olarak elde edilen verilerle 3 kod oluşturulmuştur. Bunlar: Öğrenme Ortamları, Yeterlikler ve İhtiyaçlardır.

\section{Öğrenme ortamları}

Araştırmaya katılan öğretmenlerde öğrenme ortamları algısının hizmet içi eğitim seminerleri, konferans ve toplantılarla sinırlı olduğu görülmektedir. Kariyer evrelerinin tamamında öğretmenler hizmet içi eğitim faaliyetlerinin etkisiz olduğu görüşünde birleşmektedir. Kariyere giriş evresinde öğretmenler çoğunlukla hizmet içi eğitim faaliyetlerini dile getirirken, durulma ve deneycilik/aktivizm evresinde ise öğretmenlerin öğrenme ortamı olmadığını düşünmektedir. Uzmanlık evresinde de öğrenme ortamına yönelik olumsuz algı devam ederken; sakinlik evresindeki öğretmenler, hizmet içi eğitim faaliyetlerinin olduğunu ancak etkin bir öğrenme ortamının olmadığını ifade etmişlerdir.

Kariyere giriş evresi öğretmenlerinin çoğunluğu, öğretmenlerin beceri ve yeteneklerini gerçekleştirmesi için hizmet içi eğitim faaliyetlerinin 'göstermelik olarak' düzenlendiğini ancak etkin olmadığını ifade etmiştir:

Hizmet içi eğitim faaliyetleri düzenleniyor. Ancak öğrenme ortamı olarak değerlendirmenin doğru olduğunu sanmıyorum. Çünkü çok yetersizler. (1/1)

Hizmet içi eğitim faaliyetleri gerçekleşmektedir. Ben bunlardan çok faydalanamadim ama umarım daha etkin öğrenme ortamları oluşturulur. (1/2)

Durulma, deneycilik/aktivizm ve uzmanlık evrelerindeki öğretmenlerin çoğu, kurumlarında beceri ve yetenekleri geliştirmeye yönelik herhangi bir faaliyetin gerçekleşmediğini ifade etmektedir.

Herhangi bir faaliyet düzenlenmemektedir. (2/2)

Hizmet içi eğitim dışında eğitim faaliyeti yapılmamaktadır. (4/1)

Sakinlik evresinde bulunan öğretmenlerin çoğunluğu ise kurumlarında öğretmenlerin beceri ve yeteneklerini geliştirmeye yönelik hizmet içi faaliyetler ve seminerler düzenlendiğini belirtmiştir.

Teknoloji kullanım seminerleri, iletisisim seminerleri, proje hazlrlama ve yönetmeye yönelik seminerler düzenlenmekte. (5/2)

Bakanlı̆̆ın ya da İlçe Milli Ĕgitim Müdürlüğünün faaliyetleri bulunmaktadır. Öğrenmenin sinır yok veya hizmet içi eğitim faaliyetleri. (5/4)

Sakinlik evresi dışındaki kariyer evrelerinde öğrenme ortamının olmadı̆̆ 1 ya da etkinliklerin yetersiz olduğunu düşünürken, bu evredeki öğretmenler öğretmenleri geliştirmeye yönelik faaliyetler düzenlendiğini ifade etmişlerdir.

\section{Yeterlikler}

Araştırmaya katılan öğretmenler, öğrenme ortamlarını yetersiz görürken kendilerini yeterli görmektedirler. Kariyer evrelerinin tamamında öğretmenler alanlarında yeterli oldukları ancak öğrenme ortamlarını yeterince değerlendiremedikleri ve öğrenme ortamlarının yetersiz olduğu düşüncesindedir. Kariyere giriş evresinde, teknoloji kullanımı ve iletişimde en önemli yeterlilik alanı iken, ilerleyen evrelerde teknoloji kullanımı konusunda yeterlik görüşü zayıflamaktadır. 
Kariyere giriş evresinde bulunan öğretmenlerin tamamı kendisini alan bilgisi ve bilişim teknolojisi kullanma konusunda yeterli görmektedir.

Üniversitede iyi bir eğitim aldı̆̆ıma ve kendimi geliştirdiğim için mesleğimi iyi yaptığıma inaniyorum. (1/1)

Alanımda, Iletişim, bilişim teknolojileri konularında yeterli olduğum kanaatindeyim. $(1 / 2)$

Bakioğlu (1996)'na göre, öğretim becerisi konusunda öğrenimleri sırasında eğitilmelerine rağmen kariyer girişi öğretmenleri tam eğitim alamadıklarını ve bu konuda kendilerini yetersiz algıladıklarını belirlemiştir. Bu durum katılımcı görüşlerinde ön plana çıkan iyi bir eğitim alma, bilgi teknolojilerini etkin kullanma ile açıklanabilir. Öğretmen yetiştirme konusunda üniversitelerin kendini geliştirdiği ve teknoloji kullanmada yeterli olan kariyere giriş evresi öğretmenlerinin kendilerini daha rahat geliştirdikleri düşünülebilir.

Durulma ve deneycilik/aktivizm evresindeki öğretmenlerin tamamı yerine getirdikleri görevler için kendilerini yeterli görmektedir.

Branşımda kendimi yeterli ve güçlü hissediyorum. (2/2)

Ĕgitim-ögretim faaliyetleri, alan bilgisi ve sinıf yönetimi kendimi yetkin görüyorum. (3/3)

Alanyazın incelendiğinde deneycilik/aktivizm evresindeki öğretmenlerin görüşleri ile uyum göstermektedir. $\mathrm{Bu}$ evre öğretmenlerinin çoğunluğunun kapasitesinin tamamını kullanmaya firsat bulduğunu, yüksek seviyede fiziksel ve zihinsel yeteneğin elde edildiği ve bunun enerji, gayret, hırs ile kendine güvenden kaynaklandığı belirtilmektedir. Bu evrede çoğu öğretmen sayılan özellikler yönünden zirve noktasına ulaşmış durumdadır (Sikes ve diğerleri, 1985, Akt. Bakioğlu, 1996). Görüşmelerde öğretmenlerin kendilerini mesleki açıdan yeterli gördüklerine yönelik net cevapları da bu bulgularla uyumluluk göstermektedir. Uzmanlık evresindeki öğretmenlerin de çoğunluğu alanlarında yetkin olduklarını ifade etmektedirler:

Öğrencilerimle iletişim konusunda iyi olduğumu düşünüyorum. Karakterime uygun bir branşta çallş̧yorum. (4/2)

Öğretim ve eğitim konusunda öğrencilerime çok iyi etki ettiğimi düşünürüm. (4/3)

$\mathrm{Bu}$ evre öğretmenlerinin alan bilgisi ve mesleki gelişim konusunda diğer evrelere göre alanyazınla da uygun olarak daha ihtiyatlı oldukları görülmektedir. Bakioğlu (1996), bu evredeki öğretmenlerin yarısının kariyerlerinin detayları konusunda kendilerinde bulunan kapasitenin tamamını kullanmaya imkan bulduklarını belirttiklerini ortaya koymuştur. $\mathrm{Bu}$ oran deneycilik/aktivizm evresine göre düşüş göstermiş ve bu evrede kendinde şüphe duymaya rastlanmaktadır. Bu durum öğretmenlerin kendilerini daha iyi konumlandırmaları ve hem alan hem de öğretmenlik meslek bilgisinin sınırlarının ne kadar geniş olduğunu anlamalarıyla açılanabilir. Ayrıca bu evrede öğretmenler eleştirel düşünceye sahip olmakta ve kendini kariyeri açısından tekrar değerlendirmektedir (Bakioğlu, 1996). Sakinlik evresinde bulunan öğretmenlerin tamamı mesleki anlamda kendileri yeterli gördüklerini ifade etmişlerdir.

Branşımda kendimi yeterli ve güçlü hissediyorum. Genç ögretmenlerimizin bizim tecrübemize ihtiyact var. (5/2)

Branşım konusunda yeterli hissediyorum. Mesleğimde de kendimi sürekli geliştirdim. $(5 / 4)$

Alanyazında da sakinlik evresinde yeterlik algısının arttı̆̆ına yönelik bulgular mevcuttur. $\mathrm{Bu}$ evrede profesyonel yeterlik olarak uzmanlığın ilerlediği görülmektedir (Leithwood, 1990, Akt. Bakioğlu, 1996): Sınıf içi öğretimde yüksek seviyede uzmanlık, kendi yeterlik ve seçimini ve bunların altında yatan inanç ve değerleri yansıtmak, diğer öğretmenlerin öğretim uzmanlığ kazanmalarına yardımcı olmak temel özelliklerdir. Bu evre öğretmenlerinin yeterlik konusundaki olumlu görüşleri ile rahatlama ve kendini olduğu gibi kabul etme, yaş olarak öğrencilerden uzaklaşma görülürken öğretim aktivitelerinde uzmanlığın getirdiği sakinlik yaşanmaktadır. Bu evredeki öğretmenler kapasitelerinin tamamını kullandığını ve öğretimde kendini gerçekleştirdiğini vurgulamamaktadır (Bakioğlu, 1996). 


\section{İhtiyaçlar}

Kariyere giriş evresinde öğretmenlerin yarısı iyi yetişmiş olduklarını, kendilerini sürekli geliştirdiklerini ve herhangi bir ihtiyaç duymadıklarını; diğer yarısı ise iletişim ve alanında uzmanlaşma konusunda bazı ihtiyaçlarının olduğunu düşünmektedirler.

Kişisel gelişimimle ilgili herhangi bir ihtiyaç hissetmiyorum. Çünkü sürekli kendimi geliştirdiğimi düşünüyorum. (1/1)

Terapi eğitimlerinin çeşitliliğinden dolayı, terapi eğitimlerine ihtiyaç duyuyorum. (1/4)

Durulma evresinde katılımcıların tamamı kişisel gelişimlerine katkıda sağlayan dil öğrenimi, teknoloji kullanımı, stresle başa çıkma ve drama birkaç alanda gelişmeye ihtiyaç duyduklarını belirtmektedirler.

Teknoloji kullanımı konusunda kendimi geliştirmem gerektiğini düşünüyorum. (2/2)

Kendi başarımla ve stresimle nasıl başa çıkacağım konusunda ilave bilgi ve beceriye ihtiyaç duyuyorum. (2/3)

Deneycilik/aktivizm, uzmanlık ve sakinlik evrelerinde katılımcıların çoğunluğu, kişisel gelişimlerine katkı sağlayacak öğrenme faaliyetlerine açık oldukları ve bireysel ilgi alanlarına yönelik ihtiyaçları da ifade edilmiştir.

Kendim için kişisel gelişim çalışmalarında ve öğrencilerin kişisel farklılıklarını tanıma öne çıkarmada eksiklik duyuyorum. (3/3)

Alanımın bir sınırı yok, gelişmeler açık ancak eğitim yönetim denetimi alanında bilgi ve beceriye ihtiyactm var. (4/1)

\section{Paylaşılan vizyon disiplinine yönelik algı}

Öğrenen örgütlerin öğrenme disiplinleri olarak beş disiplinden kurumun geleceğine odaklanan paylaşılan vizyon disiplini ile ilgili elde edilen verilerden 3 kod oluşturulmuştur. Bunlar: İçselleştirme, İnandırıcılık ve Sorun çözmedir.

\section{İçselleştirme}

Kariyere giriş evresinde bulunan öğretmenler kurum vizyonlarının "sadece kağıt üzerinde olduğunu ve -mış gibi yapıldı̆̆ını" ve kurumlarına ait bir vizyonun olmadığını, kurum vizyonunu benimsemenin kuruma katkısı olacağ 1 șeklinde farklı düșünmektedirler.

Kurumumuz "mış gibi” bir vizyona sahip. (1/2)

Kendi yeterliklerini bilen, sorgulayarak düşünen topluma karşı sorumluluklarını yerine getiren başartl bireyler yetiştirmektir. Kendini bilen ve sorumlulukların yerine getiren bireyler yetiştirmeyi amaçladığı için (bireyden kaynaklanan) sorunların ortadan kalkmasinı sağllyor. (1/4)

Kariyere giriş evresinde öğretmenlerin çoğunluğu, kurumlarına ait vizyonun olmadığını veya göstermelik olduğunu düşünmeleri, kurum vizyonunu henüz içselleştiremediklerini göstermektedir.. Subas (2010)'ın beş yıldan az kıdeme sahip olan öğretmenlerin paylaşılan vizyon algılarının düşük olduğunu tespit ettiği gibi alan yazında öğrenen örgütlere ilişkin araştırmalarda benzer sonuçlarla karşılaşılmaktadır.

Durulma evresinde bulunan öğretmenlerin tamamı kurumlarına ait bir vizyon olduğunu düşündükleri ancak bazılarının vizyonlarını içselleştirmedikleri görülmektedir.

Fırsat eşitliğine dayanan bir eğitim ortamı sunmak. Ancak bu vizyon gerçek durumu yansitmiyor. (2/1)

Yazılı bir vizyonum var. Fakat uygulanabilirliği konusunda şüpheliyim. (2/2)

Deneycilik/Aktivizm evresinde bulunan öğretmenlerin yarısı kurumlarına ait vizyonu tanımlarken, diğerleri ise kurumlarına ait vizyonun olması gerekliliğine inanmadığını ifade etmektedir.

Başarılı, ülkesine faydalı vicdanlı bireyler yetiştirmek. (3/1)

Kurum vizyonlarl sadece kağıt üzerinde kallyor. (3/2)

Deneycilik/Aktivizim evresindeki öğretmenlerin çoğunluğu, kurum vizyonunu içselleştiremediği görülmektedir. $\mathrm{Bu}$ bulgu alan yazınla da desteklenmektedir. Paylaşılan 
vizyonun içselleştirilmesinde görülen düşüşün bireylerdeki aşırı kendine güvenden kaynaklandığ 1 düşünülebilir.

Uzmanlık evresinde bulunan öğretmenlerin çoğunluğu, sakinlik evresinde ise tamamı kurum vizyonlarını ifade etmektedir.

Öğrenmeyi öğrenen bireyler yetiştirmek. Değissim ve gelişimleri takip eden, yeniliklere açık bireyler yetiştirmek. (4/1)

Kendi yeterlilik ve yeteneklerini bilen, okuyan, sorgulayan, bilimsel düşünen, üreten, akademik başarılarıyla bölgesinde ve ülkemizde önemli başarılar elde eden bireyler yetiştirmek. (5/2)

\section{Inandırıcilık}

Kariyere giriş evresinde bulunan öğretmenlerin tamam1, vizyonun inandırıcı olması için hedeflerin belirlenmesinde çalışanların görüşlerinin alınması gerektiğini; bazıları da kurum vizyonunun kurumsal hedefleri içermesi gerektiğini belirtmiştir.

Kurum vizyonu kurumun aynası olmalıdır. Kurum vizyonu ne kadar gerçeğe yakınsa sorunların çözümü o kadar basit olacaktır.(1/1)

Öğrenci ve ögretmen birlik içinde kuruma ait olduğunu hissettiğinde ve kurum için bir şeyler yapmaya başladiğında kurum vizyonu oluşur. Oysa şu an okulumda böyle bir şey göremiyorum. Bunun için karşıllkl fikirler dikkate alınmalı. (1/3)

Durulma Evresinde katılımcı görüşleri, öğrenen organizasyonlara yönelik araştırma (Töremen, 2001; Ertan, 2000) bulgularıyla uyuşmaktadır. Bu evrede bulunan öğretmenler vizyonun kendileri için oluşturulma şeklinden dolayı bir şey ifade etmediğini ve oluşturulan vizyonun geniş katılımla oluşturulması gerektiğini söylemektedirler.

Firsat eşitliğini sağlamak gerekliliğini ifade ediyor. Bu vizyonu müdür oluşturdu. Paydaşlarla birlikte oluşturmalıydı. (2/1)

Kurum vizyonu ögrrencinin velinin öğretmen ve idarecilerinin geniş katılımı ile oluşturulması gerektiği, ayrıca vizyonun denetlenebileceği (öğrenci, veli, ögretmen) bir sistem olmall. Bir hedef koyduk bunun için ne yaptı?? Ĕger cevap hiç ise biz dürüst olmamışız demektir ki çoğu zaman vizyonlarımızın cevabı HíÇ oluyor. (2/2)

Deneycilik/Aktivizm evresinde bulunan öğretmenlerin tamamı vizyonda belirtilen hedeflerin uygulanabilir olması gerektiğini ifade ederken uzmanlık evresinde bulunan öğretmenlerin çoğunluğu, kurum vizyonun kendileri için önemli olduğunu ancak çalışanların katılımlarının sağlanması ile oluşturulması gerektiğine vurgu yapmaktadırlar.

Vizyon toplumda görmek istediğimiz birey modelidir bence. Okulumda öğretmen arkadaşların çoğu ayn fikirde olduğundan vizyonumuz kendiliğinden oluştu. (3/1)

Kurum vizyonu çalışanların görüşleri alınarak, tartışllarak ve görüş birliği ile oluşturulmuştur. (4/1)

Sakinlik evresinde bulunan öğretmenlerin tamamı için kurum vizyonları önemli olduğunu ve oluşturulan vizyonun yeterli olduğunu düşünmektedirler.

Kurumun vizyonunun belli olmasl, bir üyesi olduğum kurumda hedefini bilen, boşu boşuna çalışmayan biri olmadığım konusundaki inancımı destekliyor. (5/2)

Olmak istediğimiz hayal ettiğimiz şey kurumun vizyonu var. Vizyon kurumun gelmek istediği nokta ideal hayali ve mutluluk diyebilirim. (5/3)

Kariyer evrelerine göre kurum vizyonun önemi, birlikte oluşturulması ve hedeflerin uygulanabilirliği konusunda görüş birliği görülmektedir.

\section{Sorun çözme}

Kariyere giriş evresinde katılımcıların çoğunluğu, vizyonun sorun çözmede katk1 sağlamayacağını düşünmektedir. 
Problemlerin ya da artı yönlerin barındırılmadı̆̆ bir vizyonla hiçbir soruna çözüm bulamazsiniz. Biz de oradayiz. (1/2)

Vizyonun oluşumu yapay olduğu için okul toplumunu oluşturan paydaşlar tarafindan özümsenememekte ve bu nedenle kuruma hiçbir etki yapmamaktadır. (1/3)

Durulma Evresinde katılımcıların yarısı vizyonun sorunların çözümüne olumlu katkı sağlayacağını, diğerleri ise sorunların çözümüne katkı sağlayamadığını ifade etmektedir.

Vizyon yasak savmak, tky dosyasını tamamlamak için yazıllyor. Bu nedenle faydası yok. $(2 / 1)$

Vizyon işbirliğini ve başarıyı arttırır. (2/3)

Deneycilik/Aktivizm evresinde öğretmenlerin çoğunluğu, vizyonun kurumda sorunları çözmede etkili olduğuna inandıklarını belirtmiştir.

Gerçekçi vizyon sorunların çözümüne tabî̀ ki olumlu anlamda katkı sağlayacaktır. Çözümü kolaylaştıracaktır. (3/2)

Başarmış ögrencileriyle gurur duymak isteği bizleri harekete geçirir. (3/4)

Uzmanlık Evresinde çoğu katılımcı öğretmen, vizyonunu tarif ederek, öğrencilerin gelecekteki başarılarına ve gelişimlerine olumlu katkı yapacağını; sakinlik evresinde de tüm katılımcılar, kurumların vizyonunun sorunların çözümüne pozitif yönde katkı sağladığını belirtmişlerdir.

Çalıştığım kurumda ortak katılımla vizyon oluşurduk. Vizyon olarak ögrenmeyi öğrenmiş ögrenciler hedefi merkezde. Bu nedenle vizyonumuzun ögrencilerimizi gelecekte hangi alanda çalışırlarsa çalışsınlar başarılı kılacağına inanıyorum. (4/1)

Vizyonumuzun net ve inandırıcı olması nedeniyle tüm çalışanlar ayn yönde ilerliyoruz.

Bu da sorunların çözümünü kolaylaştırıyor. (5/1)

Öğretmenlerin kariyerlerindeki kıdemleri ilerledikçe vizyonun sorun çözümüne olumlu katkı sağlayacağı düşüncesi öne çıkmaktadır.

\section{Sistem düşüncesi disiplinine yönelik algı}

Öğrenen örgütlerin öğrenme disiplinleri olarak beş disiplin içinde diğer dört disiplini de kapsayan sistem düşüncesi ile ilgili elde edilen verilerle 2 kod oluşturulmuştur: Sorunlar ve Çözüm arayışlarıdır.

\section{Sorunlar}

Kariyere giriş evresinde bulunan öğretmenlerin çoğunluğu, kurumda yaşanan sorunların kaynağının kurum yönetimi ve Milli Eğitim Bakanlığının bakış açısı olduğunu ifade etmiştir.

Okul idaresinin ve Milli Ĕ̈itim Bakanlığının bakış açısı, öğretmeni ve veliyi sık sı karşı karşıya getirmektedir. (1/1)

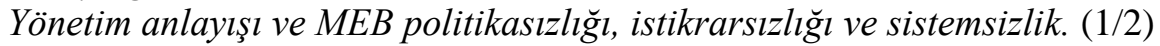

Deneycilik/aktivizm evresinde bulunan öğretmenler, sorunların kaynağını kişiler ve uygulama aksaklıklarını görmektedir.

Bireylerin kişilik özellikleri yaşam tarzları hayata bakış açılarında ki farklılıklar. (3/1)

Yapılan işlerin kağıt üstünde kalması gerçekçilikten uzak işler yapılması. (3/2)

Durulma ve sakinlik evresindeki öğretmenlerin tamamı, uzmanlık evresindekilerin çoğunluğu kurumda oluşan problemlerin kaynağı olarak kurum yönetimini, anlayış farklılıkları ve iletişimsizliği göstermektedir.

İletişimsizlik. Konuşma tembelliği olan bir toplumun alt yaplsından bir kurumun çalışanlarını oluşturmaktayız .(2/2)

Yapısal sorunlar, fiziki yap yetersizlikleri, finansman sorunları. Değişimin iyi takip edilememesi, Planlama eksikliği. (4/3)

Töremen (2001), özellikle devlet liselerindeki öğretmen ve yöneticilerin sistemli bir çalışma programına sahip olmadıklarını belirlemiş̧tir. Kariyer evrelerinin tamamı, sorunların kaynağını sistem, okul yönetimi, üst yönetim ve uygulamalar olarak görmektedir. 


\section{Çözüm arayışları}

Kariyere giriş evresinde bulunan öğretmenlerin tamamı kurumsal çözüm arayışlarında aktif rol aldıklarını, iletişim, paylaşım, ortak uygulamaları çözüm olarak ifade etmektedir.

Kurumumuzun sorunlarına ister istemez çözüm noktasında katkı sağlamaktayım. (1/1) Alınan kararlara uymak ve uygulamak sorunun en büyük çözümü olacaktır. (1/3)

Durulma evresinde bulunan öğretmenlerin tamamı çalışanların çözüm arayışlarına dahil olabilmesi için motivasyonlarının ve inançlarının arttırılmasının gerekliliğini ifade etmişlerdir.

Hedef birlikteliğine inandırarak katılabilir. (2/1)

Çalışanların gönüllülük esasına göre çalışmaya motive edilmesi etkili olacaktır. (2/4)

Deneycilik/Aktivizm evresinde bulunan öğretmenlerin tamamı çalışanların kurumsal çözüme dahil olması gerektiğini ifade etmektedir.

Herkes özgürce fikrini beyan etmek suretiyle çözüme katklda bulunabilir. (3/1)

Inanarak ve sürece istekle dahil olarak. (3/4)

Uzmanlık evresindeki öğretmenler kurumsal çözüm arayışlarında çalışanların sürece katılmaları konusunda farklı görüş ifade etmişler.

Çalışanların görüşlerine değer verildiği sürece, demokratik ve adaletli bir çalışma ve iş dağılımı yapıldığ sürece çalışanların kurumunu benimsemesi söz konusudur. (4/1)

Hiç işim olmaz. Çünkü sisteme bizim seviyemizdekilerin müdahale etmesi mümkün değil.

Her şey bizim dışımızda geliş̧iyor. (4/2)

Sakinlik evresinde bulunan öğretmenlerin tamamı çalışanların kurumsal çözüm süreçlerine aktif katılması gerektiğini ifade etmiştir.

İ̧̧birliği ve iletiş̧im süreçlerinin sağllklı işlemesi kurum kültürünün oluşması sorunların çözümünde ve çalışanların sürece katılmasında önemli rol oynar. (5/2)

Çalışanların gönülleri gibi yönetilmesi motive edilmesi sürece katılımı arttırır. (5/3)

\section{Takım halinde öğrenme disiplinine yönelik algı}

Öğrenen örgütlerin disiplinleri içinde gelişimi hızlandıran disiplin olarak tanımlanan takım halinde öğrenme ile ilgili elde edilen verilerle 2 kod oluşturulmuştur: Birlikte Öğrenme ve Mesleki Paylaşımdır.

\section{Birlikte öğrenme}

Kariyere giriş evresinde bulunan öğretmenlerin tamamı, öğretmenlerin mesleki ve mevzuat konularındaki değişimler ile farklı konularda birbirlerinden öğrendiklerini ya da bilgi aldıklarını, durulma evresindeki öğretmenlerin tamamı ise birbirlerinden yeni bilgi ve tutumlar öğrenmeyi ihtiyaç olarak gördüklerini ifade etmişlerdir.

Aslında birçok konuda bilgi paylaşımına ihtiyaç duymalarına rağmen bu durumu ihtiyaç olarak hissetmiyorlar. (1/2)

Zayıflıklarını. Maalesef zayıflıklarını ve zaaflarını öğrenmeye ihtiyaç duyuyorlar. Nadir olarak binde bir oranında bir bilgi paylaşımı yapanlarda var. (2/2)

Deneycilik/Aktivizm evresinde bulunan öğretmenler, birlik ve yardımlaşmaya ihtiyaç duyduklarını ayrıca çalışanların birbirlerinden farklı alanda öğrenme ihtiyacı duyduklarını ifade etmektedirler.

Kendisinin tamamlayamadı̆̆ diğer branşın da yardım etmesi gerektiği konularda birbirlerine ihtiyaç duyabilirler. (3/1)

Alanımız ya da diğer alanlarda çok iyi olduğumuz kanısındayım ama birbirlerimizden farklı konularda şeyler ögrenebiliyoruz. (3/2)

Uzmanlı evresindeki öğretmenlerin çoğunluğu, birbirlerinden tecrübe paylaşımı ile mesleki öğrenmeye ihtiyaç duyduklarını ifade etmektedirler.

Karşılaşılan problemlerin çözümünde elde edilen ortak tecrübe, deneyim, paylaşım. 
Yaptıklart işten nasıl haz duyabilecekleri ... vb. (4/1)

Herkes; kendi bildiğinin, alternatifine kapalı olduğu sürece kimse birbirinden bir şey ögrenemez. (4/2)

Sakinlik evresinde bulunan öğretmenlerin tamamı çalışanların birbirlerinden neyi öğrenmesi gerektiği hususunda farklı görüşler olarak;

- Mesleki bilgi,

- Teknoloji kullanımı,

- Mevzuat ve yönetmelikler,

- Kurum kültürü oluşturma, iletişim ve işbirliğini ifade etmişlerdir.

Öğretmeyi ögrrenme konusunda birbirlerine destek ve ihtiyaç duyarlar. (5/1)

Yasal mevzuatın anlaşılması ve uygulanması süreci, kurum kültürü oluşturma süreci, teknoloji kullanım becerileri konularında iletişim ve işbirliğine ihtiyaç duyarlar. (5/2)

\section{Mesleki paylaşım}

Kariyere giriş evresinde bulunan öğretmenlerin kurumlarında farklı zümrelerdeki öğretmenler arasında mesleki ilişkinin etkili olmamakla birlikte, ihtiyaç duyulması halinde paylaşımda bulunmakta çekingen davranmadıklarını ifade etmektedirler.

Kurumda bulunan farkl zümrelerdeki öğretmenler arasinda mesleki ilişki çok geliş̧kin ve etkili olmamakla birlikte, ihtiyaç duyulması halinde paylaşımda bulunmakta çok çekingen davranmamaktadirlar. (1/2)

Durulma evresinde öğretmenlerin bazıları farklı zümreler arasında herhangi bir paylaşımın olmadığını, diğerleri ise paylaşım gerçekleşse bile bu durumun asgari seviyede ve zorunluluklara bağlı olarak ortaya çıktığını ifade etmiştir.

Farklı zümreler arasında mesleki iliş̧ki kopuktur. Mesleğe iliş̧kin bilgi paylaşımı yapılmamaktadır. $(2 / 1)$

Deneycilik/Aktivizm evresinde bulunan öğretmenlerin çoğunluğu, zümreler arasında zorunlu paylaşım olduğunu ifade etmektedir.

Kendi branşımıza yakın branşlarla genelde paylaşımlar yapıllyor. Farklı zümrelerle aramdaki ilişkiler gayet iyi. (3/1)

Uzmanlık evresindeki öğretmenlerin tamamı zümreler arası mesleki ilişkileri bireysel özelliklerin belirlediğini ve bu özelliklere göre bilgi paylaşımının gerçekleştiğini vurgulamaktadır.

Mesleki ilişkileri belirleyen kişilerin bireysel iletişim becerileridir. (4/1)

Zümreler arası ilişsiler kişilere göre değişebilir. (4/4)

Sakinlik evresinde bulunan öğretmenlerin yarısı farklı zümreler arasında iletişimin yeterli olduğunu, diğer yarısı ise yetersiz gördüklerini ifade etmişlerdir. Çalışanlar arasında ise mesleki bilgi ve sorun çözme konularında bilgi paylaşımlarının gerçekleştiğini belirtmişlerdir.

Sorunları çözme noktasında bilgi paylaşımları yapmaktadırlar. (5/1)

Kurumumuzda să̆lıklı bir iletişim ortamının olduğuna inanıyorum. (5/2)

\section{Sonuç ve tartışma}

Kariyer evrelerine göre öğretmenlerin öğrenen organizasyonlarda beş disipline yönelik zihni modelleri karşılaştırıldığında, farklı kariyer evrelerinin tamamında öğretmenlerin kurum başarısı hakkında ortak algıya sahip oldukları ancak başarının önündeki engellerle ilgili farklı düşündükleri görülmektedir. Öğretmenlerin öğrenmeye yönelik algılarında kariyere giriş evresinde yönetici ve öğretmenlerin algılarında belirgin farklilıklar olduğu; durulma ve deneycilik evrelerinde ise farklılık olmadığı; uzmanlık evresindeki öğretmenlerin öğrenme algılarındaki farklılıkların öğrenen organizasyon için bir engel oluşturmadığ 1 görülmektedir. Ayrıca farklılıkların sebepleri daha nesnel olarak görülmekte ve doğal karşılanmaktadır. Alanyazında (Ertan (2000), Güçlü ve Türkoğlu (2002) öğretmenlerin kurumları ile ilgili gelecekte başarılı olacağı düşüncesini destekleyen pek çok çalışma bulunmaktadır. Bu araştırmaya katılan öğretmenlerin tamamı kurumun başarılı olması için belli şartların yerine gelmesi gerektiğini 
belirtirken, kariyerde ilerledikçe bu şartların neler olduğu daha net olarak sıralanmaktadır. Alanyazında öğretmen ve yöneticilerin öğrenen organizasyon zihni modeller algılarına yönelik Töremen (2001), Ertan (2000) ile Güçlü ve Türkoğlu (2002) öğretmenlerin daha çok sorumluluk alması gerektiğini; kurumlarda her konunun sorgulanamadığı, yenilik üretmede de yetersiz kaldığı sonuçları, bu çalışmanın bulgularını desteklemektedir. Kariyer evrelerinin tamamında kurumun başarısında en önemli faktör olarak öğretmen görülmektedir. Ancak öğretmenlerin rolü konusunda evreler arasında farklılıklar bulunmaktadır. Katılımcı öğretmenler, öğretmen beceri ve yeteneklerinin geliştirilmesi için hizmet içi eğitim faaliyetlerinde akademik anlamda gelişim sağlaması ve eğitim politikalarında değişikliğe gidilmesi gerekliliğini vurgulamaktadırlar.

Fırsatlar konusunda kariyere giriş evresinden itibaren olumlu gelişme gözlemlenmekte ve uzmanlık evresinde daha da olumlu sonuçlar çıkacağı beklenmektedir. Ancak katılımcı öğretmenler öğrenme firsatlarının faydasına inanmamakta ya da mevcut firsatların kullanılamamaktadır. Alanyazında ise Bakioğlu (1996)'na göre, katılımcıların çoğunluğu kariyerleri konusunda kendilerinde bulunan kapasitenin tamamını kullanma imkanı bulduklarını belirtmektedirler. Deneycilik/aktivizm evresindeki ivmesine oranla kariyere giriş evresinde kendinden şüpheye rastlandığını belirtmiştir. Sakinlik Evresinde öğretmenler bakanlık ve kurum düzeyinde ihtiyaçları karşılamaya yönelik çalışmaların yapıldığını belirtmektedirler. Alanyazın da bu bulguları desteklemektedir.

Zihni modellere yönelik görüşlerin en fazla çeşitlendiği, öğrenme ve öğrenme ortamlarına yönelik engeller oluşturmuştur. Töremen (2001)'in hizmet içi eğitim etkinliklerinin okulun kalitesini arttırmak için yeniden ele alınması gerektiği bulgusu, bakanlığın düzenlediği hizmet içi eğitim faaliyetlerinin yetersizliği sonuçlarını desteklemektedir. Öğrenen organizasyonlar içinde, önceden oluşan zihnî modeller yıkılmaktadır (Brestrich, 2000). Kariyer evrelerindeki öğretmenlerin çoğu önyargıların, maddi ve manevi yetersizliklerin öğrenmeyi engellediğini; bazıları da var olan öğrenme firsatlarından şartlar ve kişisel engeller sebebiyle faydalanamadıklarını ifade etmektedirler. Katılımcıların çoğunluğu öğretmenlerin öğrenme ve öğrenen organizasyona yönelik farklı bakış açılara sahip olduğunu ancak bu farklılığın öğrenmeye engel oluşturmayacağını ve bir zenginlik olarak öğrenme ortamını destekleyeceğini belirtmişlerdir. Bakioğlu (1996)'na göre durulma evresinde öğretmenler, "müfredat üzerinde kendi etkilerini görmek ve müfredatı geliştirmek istediklerinde, kurumdaki engelleri bilmek zorunda kalmakta; sakinlik evresinde ise kendine güven ve kendini kabul ile rahatlık hissettikleri görülmektedir.

Kişisel ustalık disiplini ile ilgili kariyer evrelerinin tamamında öğretmenlerin zihni modelleri kendine güvenle şekillenir ve öğretmenler kendilerini yeterli görmektedir. Bu yeterliliğin yanında farklı yeteneklerinin gelişimi için öğretim faaliyetlerine ihtiyaç duydukları ancak hizmet içi eğitim faaliyetlerinin etkisizliği hakkında fikir birliği içindedirler. Ancak sakinlik dönemi dışında tüm evrelerde öğretmenler ihtiyaç duydukları eğitim olanaklarına sahip olmadıklarını ifade etmektedir. Öğretmenlerin öğrenme ortamına yönelik algısının Bakioğlu (1996) ve Subas (2010)'ın çalışmasıyla uyuşmaması öğrenme ortamı olarak algılanan hizmet içi eğitim faaliyetlerinin kalitesi ile açıklanabilir. Hizmet içi eğitim faaliyetleri ile ilgili yapılan çalışmalarda da benzer sonuçlara ulaşıldığ görülmektedir. Töremen (2001), hizmet içi eğitim etkinliklerin okulun kalitesini arttırmak yönünde yeniden ele alınması gerektiğini, Güçlü ve Türkoğlu (2002), seminer, panel vb. toplantıların yeterli düzeyde gerçekleştirilmediğini ifade etmektedirler. $\mathrm{Bu}$ araştırmada kariyer evrelerinin tamamında öğretmenler alanlarında yeterli oldukları algılarının sebebi, öğrenme ortamlarını yeterince değerlendirememeleri ve öğrenme ortamlarının yetersiz olduğu düşünceleri görülmektedir. Durulma evresi öğretmenlerinin profesyonel gelişimleri, kariyer algılamaları ve gösterdikleri tepkilerin kariyer girişi öğretmenlerine göre daha olumluya gittiği sonuçları bu araştırmadaki öğretmenlerin görüşleri uyum göstermektedir.

Paylaşılan vizyon disiplini ile ilgili zihni modeller, kariyere giriş evresinden sakinlik evresine doğru kademe kademe değişiklik göstermektedir. Evrelerin tamamında kurum 
vizyonunun oluşturulmasında okul toplumunu oluşturan tüm unsurların katılımının sağlanamadığı, hedeflerin gerçekleştirilebilir olması gerektiği ifade edilmektedir. Ulaşılan bulgular Subas'ın (2010) paylaşılan vizyon faktöründe kıdem ilerledikçe tutumların olumlu değişimi sonucuyla uyumluluk göstermektedir. Bal (2011), paylaşılan vizyon düşüncesi açısından öğretmen algılarının öğretmenlik kıdemlerine göre farklılık gösterdiğini, öğretmenlerin kıdemleri arttıkça okullarındaki paylaşılan vizyon uygulamalarına yönelik algıları azaldığını söylemektedir. $\mathrm{Bu}$ araştırmada da uzmanlık ve sakinlik evrelerindeki öğretmenlerin çoğunluğunun görüşleri ile uyumluluk göstermektedir. Alanyazında ise Subas (2010)'ın çalışmasında, kariyerinin ilk beş y1lında olan öğretmenlerin paylaşılan vizyon algısının düşük olduğu sonucuna ulaşılmıştır. Durulma evresinde katılımcı görüşleri, öğrenen organizasyonlara yönelik araştırma bulgularıyla uyuşmaktadır. Töremen (2001), kurumlarda paylaşılmış bir vizyon olmadığını; Ertan (2000), öğretmenlerin kurumlarının vizyonlarını paylaşmada orta düzeyde kaldıkları, özellikle plânlamaların ve uygulamaların görüşleri alınmadan yapıldığını tespit etmiştir. Kariyer evrelerinin tamamında alanyazına benzer olarak katılımcı öğretmenler vizyonun önemli olduğu algısına sahip görülmektedir. Bu çalışmaya katılan öğretmenlerin kademleri ilerledikçe vizyonun sorun çözmeye olumlu katkı sağladığı görüşü önem kazanmaktadır.

Sistem düşüncesi ile ilgili zihni model tüm evrelerde bakanlık uygulamalarının olumsuzlukları ve eğitim sisteminin yanlışlıkları öne çıkmaktadır. Töremen (2001), özellikle devlet liselerindeki öğretmen ve yöneticilerin sistemli bir çalışma programına sahip olmadıklarını belirlemiştir. Kariyer evrelerinin tamamı, sorunların kaynağını sistem, okul yönetimi, üst yönetim ve uygulamalar olarak görmektedir. Takım halinde öğrenme disiplinine yönelik katılımcı öğretmenlerin birbirlerinden yeni bilgi ve tutumlar öğrenmeye, birlik ve yardımlaşmaya ve birbirlerinden tecrübe paylaşımı ile mesleki öğrenmeye ihtiyaç duyduklarını ifade etmişlerdir. Mesleki bilgi, teknoloji kullanımı, mevzuat ve yönetmelikler, kurum kültürü oluşturma, iletişim ve işbirliği öne çıkan konular olarak görülmektedir. Katılımcı öğretmenler çalışanlar arasında ise mesleki bilgi ve sorun çözme konularında bilgi paylaşımlarının gerçekleştiğini belirtmişlerdir.

Türkiye'de eğitim kurumları ve eğitim sistemi, formal olarak öğrenen organizasyon anlayışına uygun olarak yapılandırılmamıştır. Ancak; öğrenen organizasyon olarak adı konulmamış da olsa, beklenti eğitim kurumları ve eğitim sisteminin öğrenen organizasyon anlayışına uygun olarak işlev görmeleri gerektiği yönündedir. Bu nedenle, Türkiye'de eğitim kurumlarının içinde bulundukları kültür, öğretmenlerin kişisel özellikleri ve öğrenme davranışlarının öğrenen okul oluşturulmasında belirleyici olduğuna yordanabilir. Öğrenen okul oluşturma amacına yönelik birbirlerini destekleyen beş disiplin sistem düşüncesi etrafinda birbirlerini harekete geçiren sistemler olarak görülebilir. Öğrenen okulda kişisel ustalık, takım halinde ögrenme ve paylaşılan vizyon disiplinlerinin zihni modellerin şekillendirilmesinde birbirine bağlı olarak çalışmaktadır. Sistem düşüncesi, dört disiplinin her birini kapsayarak işleyişin sürekliliğini sağlamaktadır.

\section{Öneriler}

Kariyer evrelerine göre öğretmenler, kurum başarısı algıları ortak olmasına rağmen başarının önündeki engellerin kaldırılması gerektiği düşünülmektedir. Kurum başarısında en önemli faktör olarak öğretmenin beceri ve yeteneklerinin geliştirilmesi için hizmet içi eğitim faaliyetlerine öncelik verilmesi, akademik yeterliklerinin sağlaması ve eğitim politikalarında değişiklik yapılması önerilir.

Öğretmenlerin öğrenme firsatlarını kariyer evrelerine göre farklı değerlendirebildikleri ve yeterli olmamasının gereği bakanlık ve okullar düzeyinde öğrenme ihtiyaçlarını karşılamaya yönelik çalışmaların yapılması önerilir.

Kariyer evrelerindeki öğretmenlerin öğrenme ve öğrenme ortamlarına yönelik engeller konusunda önyargılı oldukları, maddi ve manevi yetersizlikler ile özel şartlar sebebiyle öğrenmelerinin engellediği; öğrenen organizasyona yönelik farklı bakış açıları sebebiyle öğrenme ortamlarının desteklenmesine yönelik önlemler alınmalıdır.

Okulların vizyonunun oluşturulmasında okul toplumunu oluşturan tüm unsurların 
katılımının sağlanması, hedeflerin gerçekleştirilebilir olmasına özen gösterilmesi önerilir.

Kariyer evrelerinin tamamında öğretmenlerin, mesleki bilgi, teknoloji kullanımı, mevzuat ve yönetmelikler, kurum kültürü oluşturma, sorun çözme, iletişim ve işbirliği konularında birbirlerinden yeni bilgi ve tutumlar; tecrübe paylaşımı ile mesleki öğrenmeye duydukları ihtiyaçları karşılamaya yönelik faaliyetler düzenlenmesi önerilir.

Türkiye'de eğitim kurumlarının kültürü, öğretmenlerin kişisel özellikleri ve öğrenme davranışlarının öğrenen okul oluşturulmasında belirleyici olduğundan öğrenen okul oluşturmaya yönelik sistem düşüncesinin öğretmenlerin önyargılarının, alg1 ve düşüncelerinin değişmesi için öğrenmenin sürekliliğinin sağlaması önerilir.

\section{Kaynaklar}

Aydın, İ., (2001). Yönetsel, mesleki ve örgütsel etik. Ankara: Pegem Yayıncılık.

Aytaç, T. (1999). Öğrenen örgüt: okul. Milli Eğitim Dergisi, 141, 75-78.

Bakioğlu, A. (1994). Okul yöneticisinin kariyer basamakları: İngiliz eğitim sisteminde yöneticilerin etkinlikleri üzerinde faktörler. M. ̈̈ Atatürk Eğitim Fakültesi Ĕ̌itim Bilimleri Dergisi, 6, 17-28.

Bakioğlu, A. (1996). Öğretmenlerin kariyer evreleri. II. Ulusalı Eğitim Bilimleri Sempozyumu, İstanbul: M.Ü. Atatürk Eğitim Fakültesi Yayınları.

Bakioğlu, A. ve İnandı, Y. (2001). Öğretmenlerin kariyer gelişimlerinde müdürün görevleri. Kuram ve Uygulamada Eğitim Yönetimi Dergisi. 7, 513-529

Bal, Ö. (2011). Illkögretim okullarında görev yapan okul yöneticisi ve ögretmenlerin ögrenen örgüt olarak okullarına iliş̧kin algıları (Yüksek lisans tezi). İstanbul: Yıldız Teknik Üniversitesi Sosyal Bilimler Enstitüsü.

Başaran, İ. E. (2000). Ĕ̈itim yönetimi nitelikli okul. Ankara: Feryal Matbaası.

Bogdan, R., ve Biklen, S. (2007). Qualitative research for education: an introduction to theories and methods. Boston, MA: Allyn and Bacon.

Braham, B. J. (1998). Öğrenen bir organizasyon yaratma. (Çev. A. Tekcan) Ankara: Rota Yayıncilik.

Brestrich, E. T. (2000). Modernizmden postmodernizme dönüşümlü liderlik. Ankara: Seba Yayınları.

Büyüköztürk, Ş. (2012). Sosyal bilimler için veri analizi el kitabı. Ankara: Pegem A.

Büyüköztürk, Ş., Çakmak, E. K., Akgün, Ö. E., Karadeniz, Ş. ve Demirel, F. (2009). Örnekleme yöntemleri bilimsel araştırma yöntemleri. Ankara: Pegem Akademi.

Can, H., Aşan, Ö., ve Aydın. M. E. (2006). Örgütsel davranış. İstanbul: Arıkan Basım Yayım Dağıtım Ltd. Şti.

Çelik, V. (2003). Eğitimsel liderlik. Ankara: Pegem A Yayıncılık.

Elma, C. ve Demir, K. (2000). Yönetimde çağdaş yaklaşımlar, uygulamalar ve sorunlar. Ankara: Anı Yayıncilik.

Ensari, H. (1998). Öğrenen organizasyon olarak okul. M.Ü. Ĕgitim Fakültesi Eğitim Bilimleri Dergisi, 10, 97-111.

Ertan, Z. (2000). Illköğretim okullarını ögrrenen organizasyona dönüşürmede yönetici ve ögretmen algıları (Yüksek lisans tezi). Ankara: Gazi Üniversitesi Eğitim Bilimleri Enstitüsü.

Fındıkçı, İ. (1996). Bilgi toplumunda yöneticilerde kendini geliştirme. İstanbul: Kültür Koleji Eğitim Vakfı Yayınları.

Fındıkçı, İ. (2004). Bilgi toplumunda eğitim ve ögretmen, yaşadıkça eğitim. İstanbul: Hayat Yayınları.

Garvin, D. A. (1999). Öğrenen bir örgüt yaratmak, Harvard Business Review Dergisinden Seçmeler: Bilgi yönetimi. İstanbul: MESS Yayınları. 
Güçlü, N. ve Türkoğlu, H. (2002). İlköğretim okullarında görev yapan yönetici ve öğretmenlerin öğrenen organizasyona ilişkin algıları. Türk Ĕ̆itim Bilimleri Dergisi, 1, 137-160.

Karasar, N. (2015). Bilimsel araştırma yöntemleri. Ankara: Nobel Yayınları.

Kaynak, T. (1996). Insan kaynaklart planlamast. İstanbul: Alfa Basım.

Koçel, T. (2003). İşletme yöneticiliği, İstanbul: Beta Yayınları.

Morgan, G. (1998). Yönetim ve örgüt teorilerinde metafor (Çev. G. Bulut). İstanbul: MESS Yayin.

Özdemir, S. (2000). Ĕgitimde örgütsel yenileşme. Ankara: Pegem A Yayıncılık.

Özden, M. C. (2001). Profesyonel kariyer yönetimi. Ankara: Ümit Yayın.

Sarıtaş, M. (2001). Sınıf yönetiminde yeni yaklaşımlar. Ankara: Nobel Yayın Dağıtım.

Senge, P. M. (2007). Beşinci disiplin (Çev. A. İldeniz, A. Doğukan). İstanbul: Yapı Kredi Yayınlar1.

Senge, P.M (2014). Öğrenen okul (Çev. M. Çetin). Ankara: M. Nobel Yayıncılık.

Subaş, A. (2010), Illköğretim okullarında çalışan sinıf ve branş öğretmenlerinin öğrenen örgütü (okulu) algılamaları. (Yüksek lisans tezi, Marmara Üniversitesi, Eğitim Bilimleri Enstitüsü, İstanbul). http://tez2.yok.gov.tr/ adresinden edinilmiştir.

Tortop, N. (1994). Personel yönetimi. Ankara: TODAİE Yayınları.

Töremen, F. (2001). Öğrenen okul. Ankara: Nobel Yayın Dağıtım.

Ünal, S. ve Ada, S. (2001). Öğretmenlik mesleğine giriş. İstanbul: Marmara Üniversitesi Teknik Eğitim Fakültesi Yayınları.

Yazıc1, S. (2001). Öğrenen organizasyonlar. İstanbul: Alfa Basım Yayım,.

Yılmaz, K. ve Altınkurt, Y. (2011). Göreve yeni başlayan özel dershane öğretmenlerinin kurumlarındaki çalışma koşullarına ilişkin görüşleri. Kuram ve Uygulamada Eğitim Bilimleri, 11, 635-650.

Yıldırım, A., ve Şimşek, H. (2005). Sosyal bilimlerde nitel araştırma yöntemleri. Ankara: Seçkin Yayınları.

\section{Extented Abstract}

\section{Introduction}

Schools, determine the individual's behavior and thoughts. Today, the active learning of the school has become a mission. The task of the education administrators in the information society is to make them a school learning school. The system approach is to be an organization that learns through the learners in organizations.

In the school environment, however, the roles of teachers responsible for teaching, giving guidance and counseling gain weight and are based on the philosophy of "lifelong education" (Ünal ve Ada, 2001). Therefore, teachers' perceptions, approaches and thoughts towards learning and forming a learning school gain importance. Because the developments that are happening nowadays force all the systems, especially education, to adapt to the changes that are experienced. For this reason, it is necessary for the organizations to maintain the continuity of learning with their continuous development. For this, it is expected that in schools, teachers will change in their intellectual approaches to learning, culture of learning, learning organization. It is aimed at changing the mindset and the attitudes that are acquired for the mindset change that is the basis of the learning. The mental models that develop the methods of thinking of these purposeful individuals are providing the models.

The system approach provides organizational teaching through the learning process through organizational dimensions. In the learning organization, five disciplines co-development is important (Senge, 2007: 15-21; çev. İldeniz, 2002). System thinking enables individuals to understand themselves and the environment in learning organizations; personal mastery is the level of competence achieved for organizational development for continuous improvement; personal dominance, the objective to see the objective and continuous improvement of personal vision. 
Learning the team, the team sees the basic learning unit. Shared Vision is a common goal shared by individuals (Senge, 2007: 206). Mental models explain the existing thought structures and perspectives. "Although people are not always consistent with what they say, they are compatible with the mental models they have and mental models are always lacking, we understand the universe through mental models" (Inceler, 1997).

\section{Method}

With this research, it has been tried to describe the mental models and professional development needs of the teachers in different branches and career stages in forming different types of educational institutions.

The main criterion determined by the researchers in the selection of teachers is the career phase of the participants. Semi-structured interview technique was used as data collection method. A semi-structured interview form was prepared to serve the purpose of the research by using literature information and expert opinions. A total of twenty teachers were interviewed at primary, secondary and high school levels, four in each career phase. Participants were asked about the five disciplines in the learning organizations and the mental models for each discipline were determined. Therefore, the codes created for each discipline at the evaluation stage were taken into consideration according to the careers and the changes in the mental models were reflected according to the career steps.

The collected data were analyzed in accordance with the qualitative research techniques and evaluated with content analysis. At this stage, the first and second researchers examined and codified each expression. A total of 19 themes were expressed in terms of five basic themes, five of which were five discipline based on the opinions collected under the codes, and the opinions of the teachers on creating a school.

\section{Result and Discussion}

According to the career stages, the participants stated that the teachers had different perspectives on learning and learning organization but that this difference would not hinder learning and would support the learning environment as a wealth.

In the literature, Töremen (2001), Ertan (2000) and Güçlü and Türkoğlu (2002) stated that teachers should take more responsibility for the perceptions of teachers and administrators about learning organizational mind models; the results of this study support the results of the fact that not every subject in question can be questioned and insufficient to produce innovation. In all of the career stages related to personal mastery discipline, teachers' mental models are shaped with confidence and teachers consider themselves sufficient. Töremen (2001) stated that inservice training activities should be re-examined to improve the quality of the school; Güçlü and Türkoğlu (2002), seminar, panel etc. they stated that the meetings were not conducted at an adequate level. In this research, the reason of the perception that teachers are sufficient in their fields in all their career stages, cannot evaluate the learning environments adequately and learning environments are inadequate.

The mental models of shared vision discipline are that the participation of all the elements of the school community cannot be achieved and that the objectives should be achievable. In the shared vision factor of Subas (2010), the positive change of attitudes and the perceptions of teachers in Bal (2011) 's shared vision idea differed according to their teaching seniority, and the perceptions of shared vision practices in their schools decreased as teachers' seniority increased. Participant teachers in the discipline of team learning it is stated that they need to learn new knowledge and attitudes from each other, to unity and to help and to share experience from each other and to learn professionally.

The idea of five disciplinary systems supporting each other for the purpose of creating a 
Işık ve Bahat

learner school can be seen as systems that activate each other. In the learner school, personal mastery, team learning and shared vision are interdependent in the shaping of mental models of disciplines. The systems thinking encompasses the continuity of operation by covering each of the four disciplines. 